\title{
Requirement for NF-kB in osteoclast and B-cell development
}

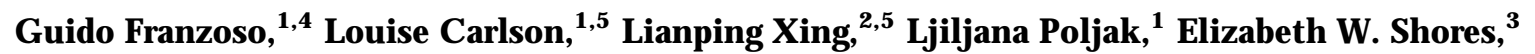 \\ Keith D. Brown, ${ }^{1}$ Antonio Leonardi, ${ }^{1}$ Tom Tran, ${ }^{3}$ Brendan F. Boyce, ${ }^{2}$ and UIrich Siebenlist ${ }^{1,6}$ \\ ${ }^{1}$ Laboratory of Immunoregulation, N ational Institute of Allergy and Infectious Diseases, $\mathrm{N}$ ational Institutes of Health, \\ Bethesda, Maryland 20892 USA; ${ }^{2}$ University of Texas Health Science Center San Antonio, San Antonio, Texas 78284 USA; \\ ${ }^{3}$ Division of Hematologic Products, Center for Biologic Evaluation and Research, Food and Drug Administration, \\ Bethesda, M aryland 20892 USA
}

\begin{abstract}
NF-KB is a family of related, dimeric transcription factors that are readily activated in cells by signals associated with stress or pathogens. These factors are critical to host defense, as demonstrated previously with mice deficient in individual subunits of NF-kB. We have generated mice deficient in both the p50 and p52 subunits of NF-kB to reveal critical functions that may be shared by these two highly homologous proteins. We now demonstrate that unlike the respective single knockout mice, the p50/ 552 double knockout mice fail to generate mature osteoclasts and B cells, apparently because of defects that track with these lineages in adoptive transfer experiments. Furthermore, these mice present markedl y impaired thymic and splenic architectures and impaired macrophage functions. The blocks in osteoclast and B-cell maturation were unexpected. Lack of mature osteoclasts caused severe osteopetrosis, a family of diseases characterized by impaired osteoclastic bone resorption. These findings now establ ish critical roles for NF-kB in development and expand its repertoire of roles in the physiology of differentiated hematopoietic cells.
\end{abstract}

[Key Words: N F-кB; knockout mice; osteopetrosis; B cell; devel opment; osteoclasts]

Received September 30, 1997; revised version accepted N ovember 4, 1997.

M ammal ian N F-кB transcription factors are dimers composed of various combinations of the structurally related proteins p50 (N FKB1), p52 (N FKB2), p65 (RelA), c-Rel (Rel), and RelB. These proteins all share a so-called "Rel homology domain," that encodes DNA-binding motifs, the dimerization interface, and a nuclear local ization sequence. p65, c-Rel, and RelB, but not p50 and p52, also contain transcriptional activation domains unique to each of these proteins. p50 and p52 are generated by proteolytic processing from p105 and p100 precursors, respectively. N F-kB dimers are generally retained in the cytoplasm by association with the inhibitory $I_{\kappa} B$ proteins. Upon appropriate cellular stimulation, most often by signals related to stress or pathogens, the inhibitors are proteolytically degraded and the NF-кB factors translocate to the nucleus. There they bind to $\mathrm{kB}$ DN A elements to induce transcription of a large number of genes, especially those concerned with immune or stress responses (for review, see Baeuerle and Henkel

\footnotetext{
${ }^{4}$ Present address: Gwen Knapp Center for Lupus and Immunology Research and The Ben May Institute for Cancer Research, The University of Chicago, Chicago, Illinois 60637 USA.

5These authors made equally significant contributions and are listed in al phabetical order.

${ }^{6}$ Corresponding author.

E-MAIL US3N@NIH.GOV; FAX (301) 402-0070.
}

1994; Si ebenlist et al. 1994; Verma et al. 1995; Baldwin 1996).

Analyses of mice deficient in individual members of

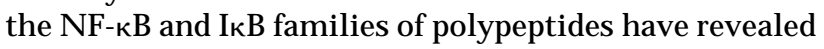
essential roles for these factors in immune responses; in particular, they indicate a need for NF-kB in signal-induced responses of differentiated cells of the immune system. Each of these knockout mice presented with a distinct spectrum of defects (Beg et al. 1995a,b; Burkly et al. 1995; Kontgen et al. 1995; Sha et al. 1995; Weih et al. 1995, 1996, 1997; Gerondakis et al. 1996; Grigoriadis et al. 1996; Klement et al. 1996; Michaelson et al. 1996; Snapper et al. 1996a,b; DeKoning et al. 1997; Doi et al. 1997; Franzoso et al. 1997; Horwitz et al. 1997; Schwarz et al. 1997; Franzoso et al. 1998). Thus, individual mammalian N F-kB proteins have unique and essential functions in defense of the host against pathogens.

Little is known of the possible roles of N F-кB in mammalian development. Although the Drosophila NF-kB homol og Dorsal is responsible for devel opment of all embryonic ventral structures (Belvin and Anderson 1996), a similar role has not been shown in mammals. N evertheless, recent studies in mice are beginning to uncover other devel opmental roles for N F-кB. Mouse fetal liver cells deficient in both p50 and p65 have been postulated to lack an extracel lular-acting factor necessary for development of early lymphocyte precursors, al though nei- 
ther cellular origin nor identity of this factor is known (Horwitz et al. 1997). Lack of p65 results in hepatocyte apoptosis in utero (Beg et al. 1995b), but it remains to be determined whether this reflects a developmental defect intrinsic to these cells. Finally, transgenic mice expressing a dominant-negative $I_{\kappa} B-\alpha$ protein in $T$ cells are impaired, albeit only partially, in generation of mature, peripheral T cells, in particular CD8 ${ }^{+}$cells (Boothby et al. 1997).

Because mammalian NF-kB complexes may have redundant activities, micelacking individual family members may not reveal the full range of critical functions executed by this transcription factor family. To eliminate possible redundancies and to better understand the biologic roles of NF-kB factors in vivo, including possible developmental roles, we have generated mice deficient in both p50 and p52. These two subunits are highly homologous and are usually coexpressed, and they are the most frequent partners of the transactivating family members p65, c-Rel, and RelB (for review, see Baeuerle and Henkel 1994; Siebenlist et al. 1994; Verma et al. 1995; Baldwin 1996). Consistent with the elimination of a majority of partly redundant NF$\kappa \mathrm{B}$ complexes, the double knockout mice exhibited defects not seen with either the p50 or the p52 single knockout mice (Sha et al. 1995; Franzoso et al. 1998). Double knockout mice are impai red in the development of osteoclasts and B cells, and the defects appear to lie within the respective cell lineages. Mutant mice also displayed multiple defects in differentiated cell functi ons not seen in the single knockout mice. The inability to generate mature osteoclasts in double knockout mice resulted in severe osteopetrosis. A critical involvement of NF-кB in osteoclast devel opment and, therefore, bone remodeling was unexpected, and a necessary role in development of mature B cells had not been shown previously.

\section{Results}

Severe osteopetrosis in p50 and p52 double knockout mice

Double knockout mice were derived from p50 and p52 single knockouts by interbreeding first generation mice heterozygous for each locus (Sha et al. 1995; Franzoso et al. 1998; see M aterials and M ethods). In the progeny, double knockout mice were identified with the expected frequency of $\sim 1$ in 16. However, they had retarded growth, which became apparent within 1 week of birth. Typically, the pups succumbed shortly after weaning when they were 3-4 weeks old, presumably because of failure of their incisor teeth to erupt (although other defects probably contributed; see below). Failure of tooth eruption is characteristic of osteopetrosis, a disorder of bone remodeling caused by impaired osteoclast formation or function (Popoff and Marks 1995). These cells normally function to resorb bone. Mice in which any three of the four alleles for p50 and p52 were mutant also had retarded growth and reduced survival but generally lived up to a few months and their teeth erupted normally.

Further indication of osteopetrosis was obtained by whole-body anteroposterior radiographs of 2- to 4-weekold double knockout mice and their littermate controls. The mutant mice had shortened long bones that were radio-opaque and lacked proper bone marrow cavities, (Fig. 1A, left panels). Furthermore, lateral radiographs of mutant animals showed that the incisors had failed to erupt into the oral cavity (Fig. 1A, right panels). Histologic analysis of Iongitudinal sections cut through fore- and hindlimbs of the double knockout mice confirmed severe osteopetrosis, the marrow cavities being filled with unremodeled osteocartilaginous matrix (Fig. 1B). Staining of bone sections for tartrate-resistant acid phosphatase (TRAP)—an enzyme that is highly expressed in osteoclasts (Minkin et al. 1982)-showed abundant, strongly $\mathrm{TRAP}^{+}$cells in the metaphyseal bone of wild-type mice. No TRAP ${ }^{+}$osteoclasts were seen in most sections cut from the bones of double knockout mice (Fig. 1C; occasionally, one or two osteoclasts were seen in sections of osteopetrotic limbs, but the intensity of the TRAP staining in these few cells was very weak). Multinucleated mature osteoclasts $\left(\right.$ TRAP $\left.^{+}\right)$, as well as their mononuclear, TRAP ${ }^{+}$ precursors, were missing in mutant but not wild-type mice, suggesting that p50 or p52 is required for TRAP ${ }^{+}$ osteoclast precursor formation. Furthermore, we saw no evidence of apoptosis of osteoclasts or of their mononuclear precursors to account for the absence of osteoclasts. Thus, in the absence of these transcription factors, osteoclast development was halted at a stage prior to expression of TRAP, resulting in severe osteopetrosis.

Impaired development of osteoclasts tracks with this cell lineage in adoptive transfers

Previous studies of naturally occurring or genetically engineered forms of osteopetrosis indicate that failure of osteoclast formation may result from defects associated with either accessory (osteoblast/stromal) cells or with cells of the osteoclast lineage (Y oshida et al. 1990; Soriano et al. 1991; Takahashi et al. 1991; Wang et al. 1992; Grigoriades et al. 1994; T ondravi et al. 1997). To address this issue we performed in vitro coculture experiments in which the generation of functional osteoclasts from splenic precursors is dependent on supportive stromal cells/ osteoblasts. Primary osteoblasts, derived from calvariae of newborn mice were cocultured with splenocytes on thin slices of dentine, the bone-like matrix of teeth. Functional osteoclasts were formed from wildtype precursors present in spleen, regardless of the source of osteoblasts, wild-type or mutant, as determined by TRAP positivity and formation of resorption pits (Fig. 2A). However, functional, mature osteoclasts were not formed with splenocytes of double knockout mice as the source of osteoclast precursors (Fig. 2A). These findings suggest that the primary defect tracks 
Figure 1. Severe osteopetrosis in p50 and p52 double knockout mice. (A) Radio-opaque long bone shafts and failure of incisor teeth to erupt in double knockout mice. Shown are whole body anterior-posterior (left panels) and skull lateral (right panels) radiographs of a 4-week-old double knockout mouse (dKO, bottom panels) and a wild-type littermate control (WT, top panels). (Middle panels) Enlargement of the boxed areas in the left panels to document the absence of a normal marrow cavity in the femur of a mutant mouse. (B) N ormal marrow cavity of an 8-day-old control heterozygote mouse (WT) (p50 $(+/-), p 52(+/-)$, which was indistinguishable from a true wild-type mouse) and marrow cavity from an 8-day-old double knockout (dKO) mouse, which is largely filled with unremodel ed osteocartilaginous matrix. Shown are hematoxylin and eosin (HE) (B) and TRAP (C) staining of Iongitudinal sections through proximal tibiae. (C) Absence of TRAP ${ }^{+}$ cells in double knockout mice. A different pair of 8-day-old mutant mouse (dKO) and control littermate (WT) was used in C [WT control in C was p50 $(H+), p 52(+-)]$, which was indistinguishable from a true wild-type animal). Osteopetrosis and lack of osteoclasts were confirmed histologically in six double knockout mice, aged 3-4 weeks. M ean values ( \pm S.D.) are for cancel lous bone volumes in sections of humeri from five dKO mice $42 \pm 7 \%$ vs. $3.4 \pm 1 \%$ in seven $\mathrm{p} 50(+/+)$, p52 $(H \rightarrow$ mice. Original magnifications were $4 \times(\mathrm{HE})$ and $40 \times(\mathrm{TRAP})$.
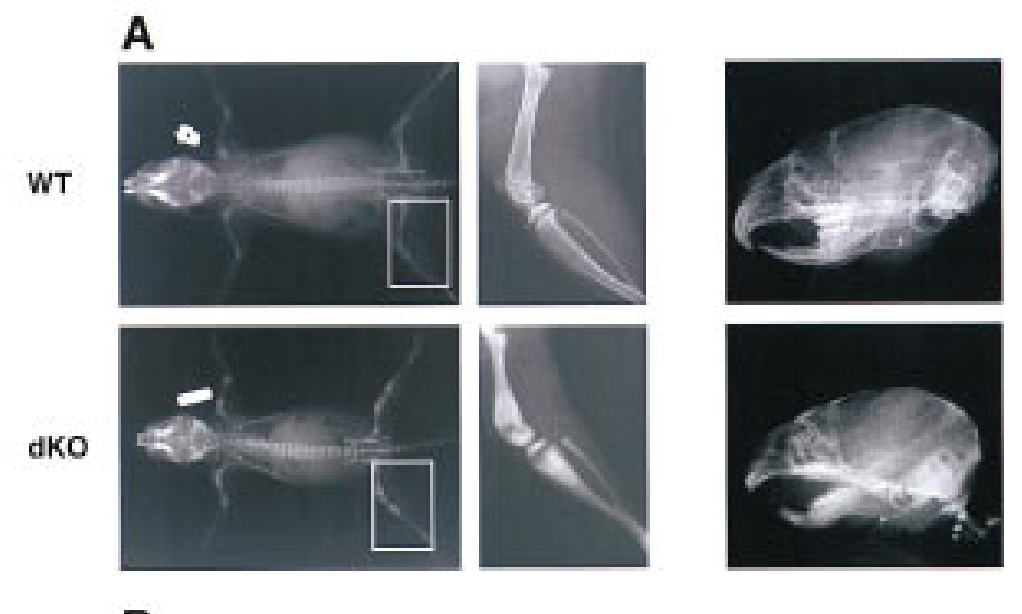

B
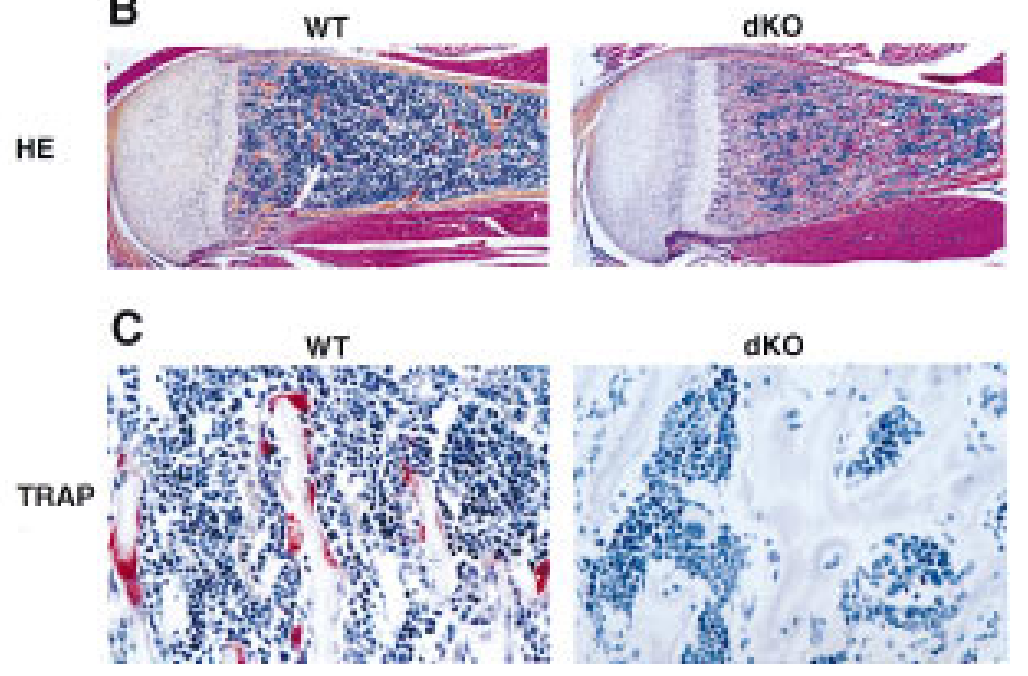

with cells of the osteoclast lineage, rather than with cells of stromal origin, such as osteoblasts.

If defects reside in the osteoclast lineage, then the osteopetrotic phenotype should be rescued by adoptive transfers into newborn double knockout animals of cells from wild-type fetal livers, which contain osteoclast and other hematopoietic precursors but not stromal precursors (Lowe et al. 1993). When wild-type fetal liver cells were injected into lethally irradiated 3- to 6-day-old double knockout mice, tooth eruption was observed in these mice 5 weeks after birth, a finding consistent with rescue of the osteoclast defect (Fig. 2B, right panels). Rescue of the osteopetrosis could also be demonstrated both radiologically and histologically by the appearance of normal bone marrow cavities and cortices of normal thickness (Fig. 2B, left panels). N umerous TRAP ${ }^{+}$osteoclasts and mononuclear cells were now observed along the bone surfaces (Fig. 2C). Rescue of the osteopetrosis was also observed in mutant mice given a transfer of wild-type bone marrow cells (data not shown). These results support the conclusion that a defect tracking with the osteocl ast lineage is responsible for the developmental block in osteoclast formation in p50 and p52 double knockout mice.

\section{Impaired macrophage functions}

To address whether development in p50- and p52-deficient mice might be arrested at a precursor common to both macrophages and osteoclasts (Yoshida et al. 1990; Takahashi et al. 1991; Tondravi et al. 1997), we stained liver and spleen sections for the macrophage marker F4/ 80 (Leenen et al. 1994). As we observed F4/80+ cells in both of these organs of double knockout mice, the block to osteoclast formation could not have occurred at an early precursor stage common to both cell types (for spleen sections, see Fig. 4B, bel ow).

Although macrophage development was not hal ted at an early stage in double knockout mice, some mature macrophage functions were impaired. Following stimulation with lipopolysaccharide (LPS), thi oglycol late-elicited mutant macrophages fail ed to induce significant levels of granulocyte-macrophage col ony-stimulating factor (GM-CSF) and G-CSF mRN A (Fig. 2D). Also, induction of M-CSF mRNA appeared to be defective in mutant macrophages, although the basal level of expression of this mRN A was al ready increased over that of control macrophages. In addition to these dramatic changes, LPS-mediated induction of mRNAs for several other 

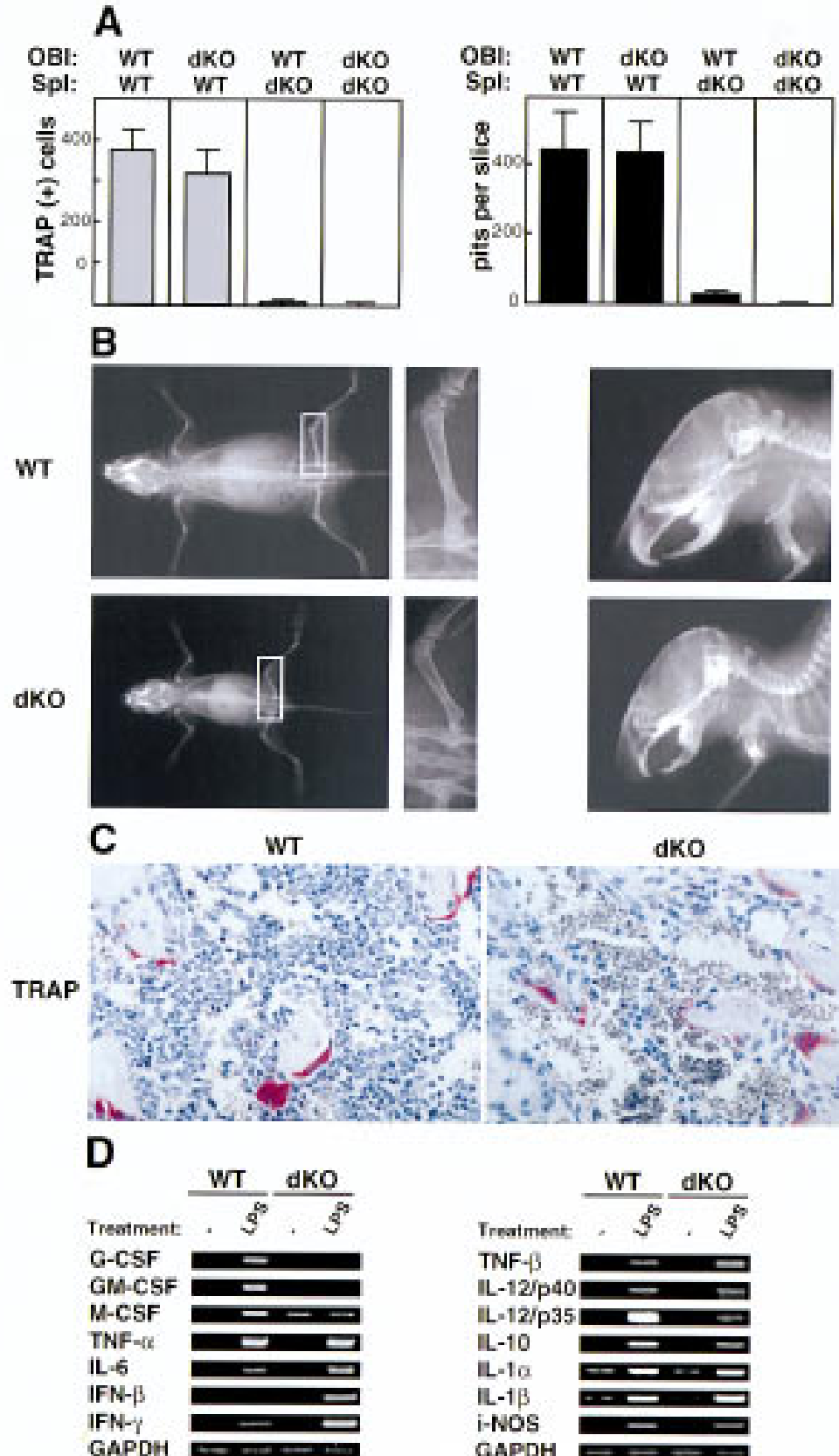

GAPDH
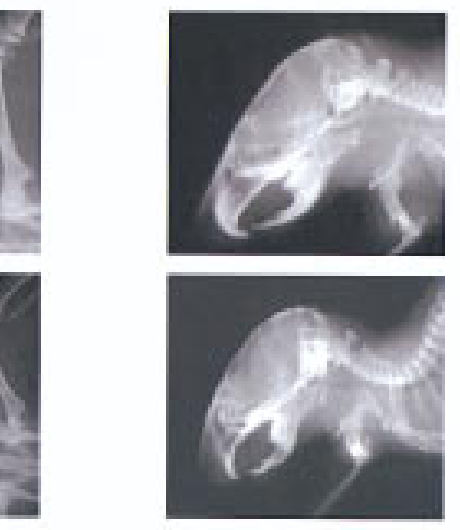

dKO
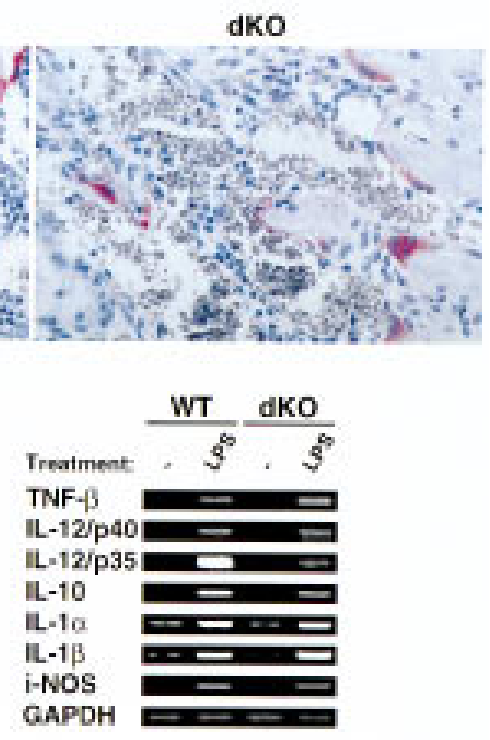

Figure 2. The osteopetrotic phenotype is due to a defect intrinsic to the osteoclast cell lineage. (A) Impaired development of double knockout osteoclasts in vitro. Primary osteoblasts $(\mathrm{OBI})$ isolated from the calvariae of newborn wild-type (WT) or double knockout (dKO) mice were cocultured with spleen cells (Spl) isolated from either wild-type or mutant mice for 20 days on dentine slices in the presence of $10^{-8} \mathrm{M} 1,25$ dihydroxyvitamin $\mathrm{D}_{3}$. TRA $\mathrm{P}^{+}$osteoclasts (left) and resorption pits (right) were counted after the culture period. M eans and standard errors were calculated from six dentine slices per group. Data shown are representive of three separate experiments. (B) Osteopetrosis is cured by wild-type fetal liver transfer. Formation of radiologically clear marrow cavities within the shafts of long bones (left and middle panels) and normal tooth eruption (right panels) in adoptively transferred double knockout (dKO, bottom panels) and littermate control (WT, p50( $+/-$, p52 $(+/-$, top panels) mice. Four-day-old double knockout mice and littermate controls were lethal ly irradiated and injected intraperitoneally (i.p.) with wild-type fetal liver cells (day 14). Whole body (left and middle panels) and skull lateral (right panels) radiographs were taken 4.5 weeks after injection. Middle panels represent an enlargement of the inset in the left panels. (C) Presence of numerous TRAP ${ }^{+}$ osteoclasts in proximal tibia sections of adoptively transferred double knockout mice. The control littermate that was adoptively transferred was a p50 $(+H$ $+)$, p52 $(+t-)$ mouse. Mice were analyzed 3.5 weeks after fetal lever cell transfer, when their cancellous bone volumes were $7.8 \%$ and $4.7 \%$ in two rescued double knockout mice and $5.5 \%$ and $6.2 \%$ in two rescued wild-type mice. (D) Altered gene expression in double knockout mice. RT-PCR was performed on RN A extracted from thioglycollate-elicited macrophages obtained from two pairs of 3-week-old littermates (WT, p50( $+/+)$, p52 $(+/-)$, and dKO). Cells were isolated from the peritoneal cavity, allowed to adhere to plastic, and then treated with LPS for $2 \mathrm{hr}$ or left untreated, as indicated. PCR primers and animal genotypes are as indicated. Identical results were obtained in two independent experiments, and data from a representative pair of mice are shown. Data shown in the left and right panels are from two independent RT reactions (GAPDH controls at the bottom of each set).

cytokines appeared to be either partially blocked (IL12/ p35, IL10) or partially increased [ $\beta$-interferon (IFN- $\beta$ ), IFN $-\gamma$, and tumor necrosis factor- $\beta$ (TNF- $\beta$ )], al though more quantitative anal yses are required to confirm these less dramatic changes. Together, these data indicate that p50- and p52-containing complexes play important roles in differentiated functions of macrophages, where they may act either directly or indirectly as both transcriptional repressors or activators.

Impaired development of B cells and defects in splenic architecture

Flow cytometric (FCM) anal yses of splenocytes from $\sim 2$ - week-old double knockout mice consistently revealed a modest reduction (1.3- to 2.6-fold) in the rel ative amount of $\mathrm{B} 220^{+} \mathrm{B}$ cells when compared to wild-type controls (Fig. 3, spleen, left panels). The IgM ${ }^{+} B$ cells were, however, significantly reduced and $\mathrm{IgD}^{+}$cells were nearly undetectable (Fig. 3, spleen, left panels), suggesting an absence of mature IgM and IgD double-positive B cells. In support of this notion, splenocytes from double knockout mice exclusively expressed lower levels of B220 and profoundly reduced levels of I-A ${ }^{\mathrm{b}}$ [major histocompatibility complex (MHC) class II] per cell and were nearly negative for CD23 (Fig. 3, spleen, left panel s). The data indicate the absence of mature cells and the presence only of pro-B, pre-B, or immature B cells. In con- 
trast, mature $B$ cells were readily observed in littermate controls (B220 $0^{\text {bright }}, C^{2} 23^{+}$, I-A $\left.^{\text {b bright }}\right)$. We concl ude that
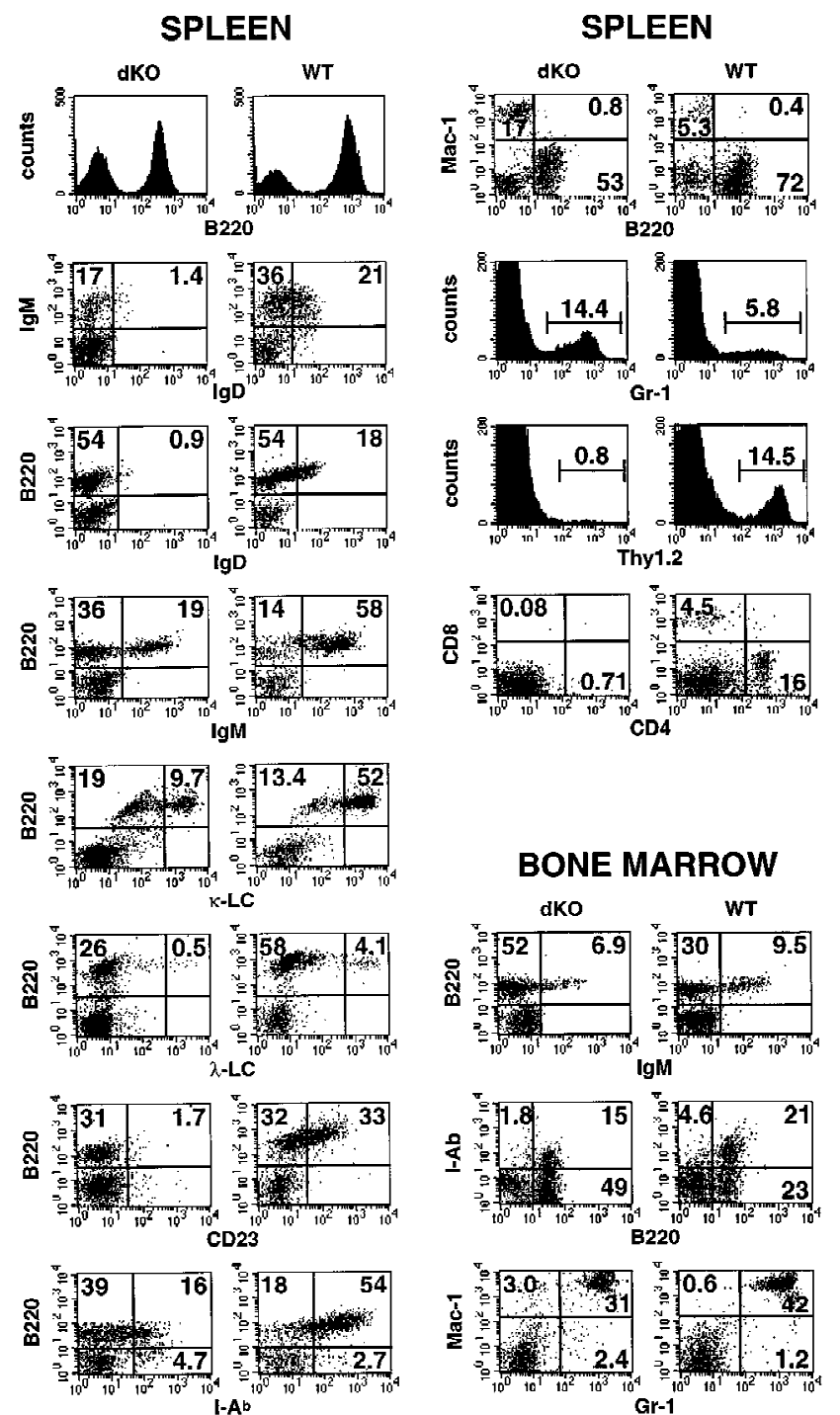

Figure 3. Defects of $B$ and $T$ Iymphocytes in double knockout mice. Three-color FCM analysis of spleen and BM cell suspensions from 13- to 15-day-old double knockout mice (dKO, left panels) and $\mathrm{p} 50(+/+), \mathrm{p} 52(+/)$ littermate controls (WT, right panels). Two-color profiles or single-color histograms are displayed. The data are taken from analyses of three representative sets of mice, but the results were confirmed with two additional pairs. The following antibodies (Iisted top to bottom and left to right) were used. Spleen: B220-biotin, IgD-FITC vs. IgM-biotin; IgD-FITC vs. B220-PE; IgM-biotin vs. B220-PE; $\kappa$-light chain (LC)-FITC vs. B220-PE; $\lambda$-LC-FITC vs. B220-PE; CD23-FITC

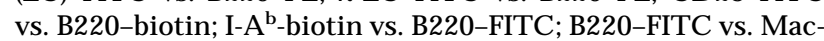
1-PE; Gr-1-FITC; Thy1.2-biotin; and CD4-biotin vs. CD8a-PE. Bone marrow: IgM-biotin vs. B220-PE; B220-FITC vs. class II

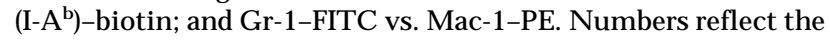
percentage of positively stained cells. The percentage of $\mathrm{B}_{2} 2 \mathrm{O}^{+}$ BM cells was modestly increased in mutant mice, whereas class II expression was more intense in wild-type BM, even though fully mature cells were nearly absent, as judged by lack of expression of IgD (not shown). development of double knockout $\mathrm{B}$ cells is halted at an immature stage $\left(\mathrm{CD}_{19^{+}}, \mathrm{B}_{2} 20^{\mathrm{low}}, \mathrm{CD}^{2} 3^{-}, \mathrm{IgM}^{+}, \mathrm{IgD}{ }^{-}\right.$, and class II low expression; for review, see Rajewsky 1996; Duchosal 1997; Melchers 1997).

Previous studies with cultured cell lines have sug-

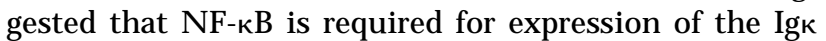
locus, controlling rearrangement and/or transcription of the locus (Kirillov et al. 1996; Scherer et al. 1996). N everthel ess, $\mathrm{k}$ light chains were expressed on splenocytes of double knockout mice, as determined by FCM analyses, and although the number of positive cells was low, consistent with the reduced number of $\mathrm{IgM}^{+}$cells, the amount expressed per cell appeared normal (Fig. 3, spleen, left panels). Furthermore, no skewing toward $\lambda$ light-chain expression was noted. These results were confirmed by immunohistochemical anal yses of spl eens of double knockout mice (data not shown). Therefore, N F-кB complexes containing p50 or p52 are not essential for $\kappa$ expression.

FCM analyses of bone marrow (BM) cells revealed no further obvious deficiencies of mutant mice, although considerably fewer cells were recovered from these mice than from littermate controls. As expected, mature B cells were absent in mutant BM, as judged by the markers shown (Fig. 3, bone marrow panels), as well as by lack of expression of IgD (data not shown); however, mature cells were usually present at only low levels in wild-type BM as well, at least in these very young mice (Fig. 3, bone marrow panels). We conclude that absence of p50 and p52 blocks the development of mature B cells at a stage that normally coinci des approximately with exit of normal B cells from the BM. B cel Is appear to progress to an immature stage, as indicated by the presence of IgM ${ }^{+}$ cells. Progression past the pro-B cell stage in BM was al so confirmed by the presence of $\mathrm{B}_{220^{+}}, \mathrm{CD} 43^{-}$cells, as CD43 is down-regulated as B cells advance past the proB-cell stage (data not shown). Although it is possible that progression through early stages of development may have been quantitatively affected in double knockout mice, the data suggest that a definite bl ock occurred only at the immature IgM ${ }^{+}$stage of B-cell development.

Spleens of double knockout mice contained a higher proportion of $\mathrm{Mac}-\mathrm{I}^{+}$monocyte/macrophages and $\mathrm{GR}-\mathrm{I}^{+}$ granulocytes than those of wild-type littermates, but this was likely a reflection of the relative decrease in other cells: In addition to the noted decrease in B cells, we observed almost no $T$ cells in mutant spleen, a point that will be discussed in more detail below (Fig. 3, spleen, right panels; Thy1.2, CD4, and CD8 markers). $\mathrm{N}$ o signs of inflammation were noted (data not shown). Unlike spleens, BM of double knockout mice contained near normal proportions of $\mathrm{GR}-1^{+}$and $\mathrm{Mac}-1^{+}$cells (Fig. 3, bone marrow panels).

Histologic analysis demonstrated a severel y disrupted splenic architecture in double knockout mice, with no white pulp present [Fig. 4A, hematoxylin/eosin (HE) stain]. Furthermore, no lymph node structures could be identified in double knockout mice upon gross anatomic examination. In spleens, weakly staining B $220^{+}$B cells were diffusely distributed and only a few rare $T$ cells 

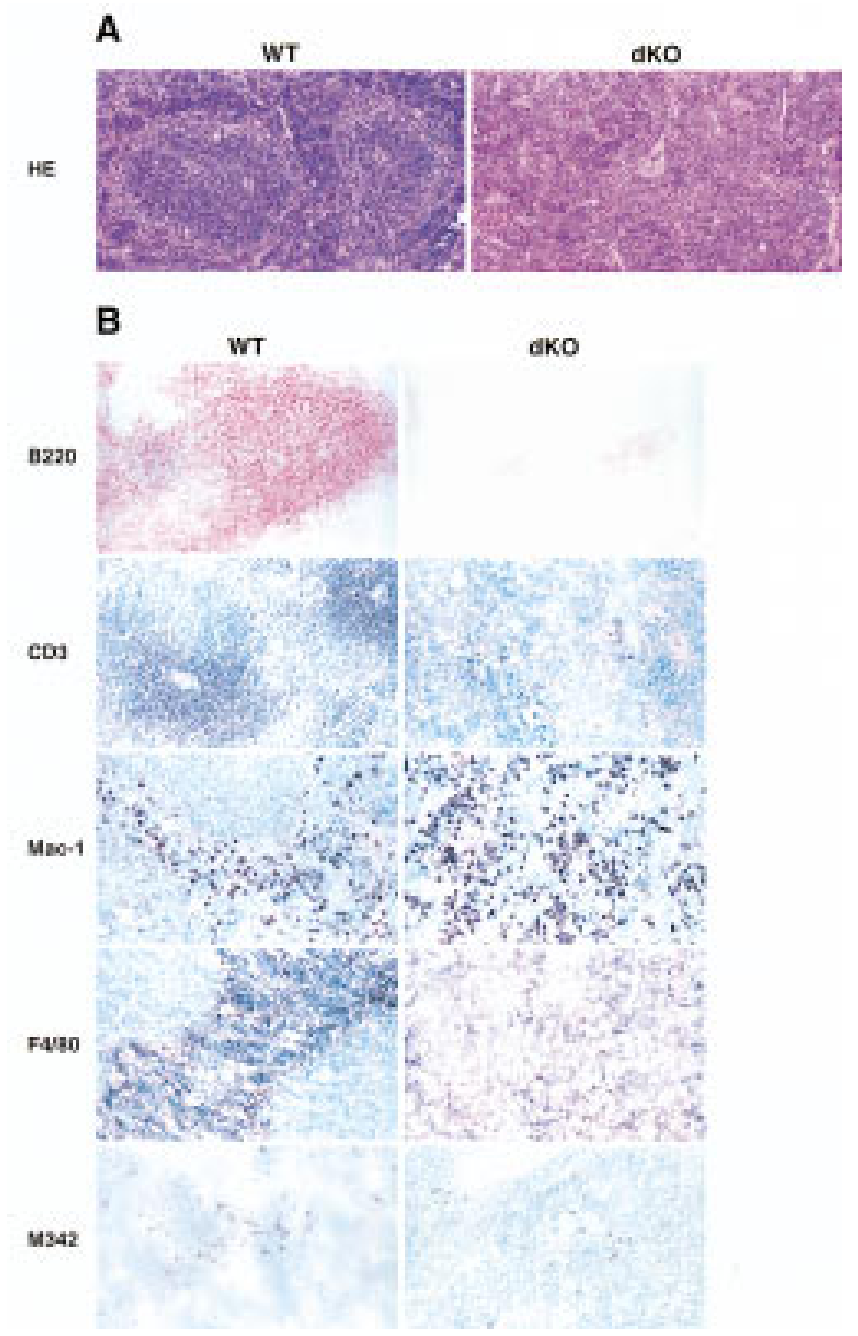

Figure 4. Histological abnormalities in spleens of double knockout mice. (A) Spleens of mutant mice lack white pulp. Bouin's-fixed paraffin-embedded sections were obtained from spleens of a 10-day-ol d double knockout mouse (dKO, right panels) and a wild-type littermate (WT, left panels) and stained with $\mathrm{HE}$, as indicated. (B) Absence of B- and T-cell areas in spleens from 2- to 4-week-old double knock-out mice (dKO) and littermate controls (WT) (right and left panels, respectively). Control littermates in A and B were p50 $(+/+)$, p52 $(+/-$, except for macrophage marker panels, in which the control was p50(t/-), p52 $(H+)$. Acetone-fixed, frozen sections were processed with anti-B220, anti-CD3, anti-macrophage (Mac-1 and F4/80) or anti-dendritic cell (M 342) antibodies, as indicated. HRP-conjugated secondary anti bodi es were used, except for the B220 staining where the secondary antibody was AP conjugated. Stained cryosections from representative pairs of littermates are shown.

were noted (Fig. 4B, B220 and CD3 markers; see below). $\mathrm{Mac}-1^{+}$and $\mathrm{F} 4 / 80^{+}$macrophages were present throughout the spleen, whereas these cells are normally excluded from the white pulp, as seen in control mice (Fig. 4B). M $342^{+}$interdigitating dendritic cells (DCs) were present in mutant spleens, but they were generally fewer in number and were not as organized as those seen in littermate controls (Fig. 4B; Breel et al. 1987; Agger et al. 1992).
Defective maturation of B cells tracks with this cell lineage in adoptive transfers

Mice deficient in RAG-1 (recombination activation gene-1, hereafter referred to as RAG-1 mice) lack both T and B cells (M ombaerts et al. 1992). To test whether the defect in development of B cells is associated with these hematopoietic cells or due to defects in other cells known to interact with B cells, that is, stromal cells, irradiated RAG-1 mice were reconstituted with BM of double knockout mice. FCM analyses of adoptively transferred RAG-1 mice reveal ed engraftment of hematopoietic cells from double knockout BM. CD ${ }^{+} / \mathrm{T}$-cell receptor $\left(T C R^{+}\right)$double knockout $T$ cells were abundant in spleen and lymph nodes of chimeric mice (Fig. 5A,B, see below for further discussion). In contrast, $\mathrm{B}^{2} 2 \mathrm{O}^{+} \mathrm{B}$ cells and, in particular, $\operatorname{lgM}^{+} B$ cells were reduced in number in spleens of RAG-1 mice having received mutant BM, as compared to RAG-1 mice having received wild-type BM (Fig. 5A, spleen, left panels). Importantly, the $B$ cells generated from mutant precursors were profoundly lacking in IgD and CD 23 and expressed only low levels of B220 and I-A ${ }^{\text {b }}$ (Fig. 5A, spleen, all panels) indicating the absence of mature $B$ cells, whereas $B$ cells of earlier developmental stages were present. These data demonstrate that the developmental arrest of double knockout B cells occurred in the RAG-1 background as well, suggesting that the defect tracks with the B-cell lineage. Development is halted at an immature stage, prior to expression of mature B-cell markers. The immature mutant B cells, though present in spleens of RAG1-recipient mice, failed to populate lymph nodes, as determined by FCM (Fig. 5A, lymph nodes) and immunohistochemistry (not shown).

Immunohistochemical analyses of spleens of RAG-1 mice adoptively transferred with double knockout BM showed organized T cells (CD3 ${ }^{+} \mathrm{T}$ cells; see below) in the periarterial lymphoid sheaths (PALS) but only few, relatively disorganized B220+ B cells (Fig. 5B). In further agreement with the FCM analyses, these $B$ cells did not express $\operatorname{lgD}{ }^{+}$(not shown); they were also unable to form peanut agglutinin (PNA $)^{+}$clusters, a hallmark of germinal centers, following challenge of the chimeric mice with 2, 4, 6-trinitro-phenyl-keyhol e limpet hemocyanin (TN P-KLH) (MacLennan 1994; Liu and Banchereau 1996). As expected, $\mathrm{PN} \mathrm{A}^{+}$germinal centers were readily detected in the control RAG-1 mice that had received BM from wild-type mice (Fig. 5B, double staining for B220 and PNA). We conclude that double knockout B cells arrest at an immature stage of devel opment, apparently because of a defect associated with this lineage, and that the arrested cells are not immunocompetent, as they are unable to form germinal centers in response to antigen, a function of mature $B$ cells.

\section{T cells and defective thymic architecture}

Thymus glands of double knockout mice yielded between 10- and 30-fold fewer cells than those of their control littermates (Fig. 6A). FCM analyses revealed a 


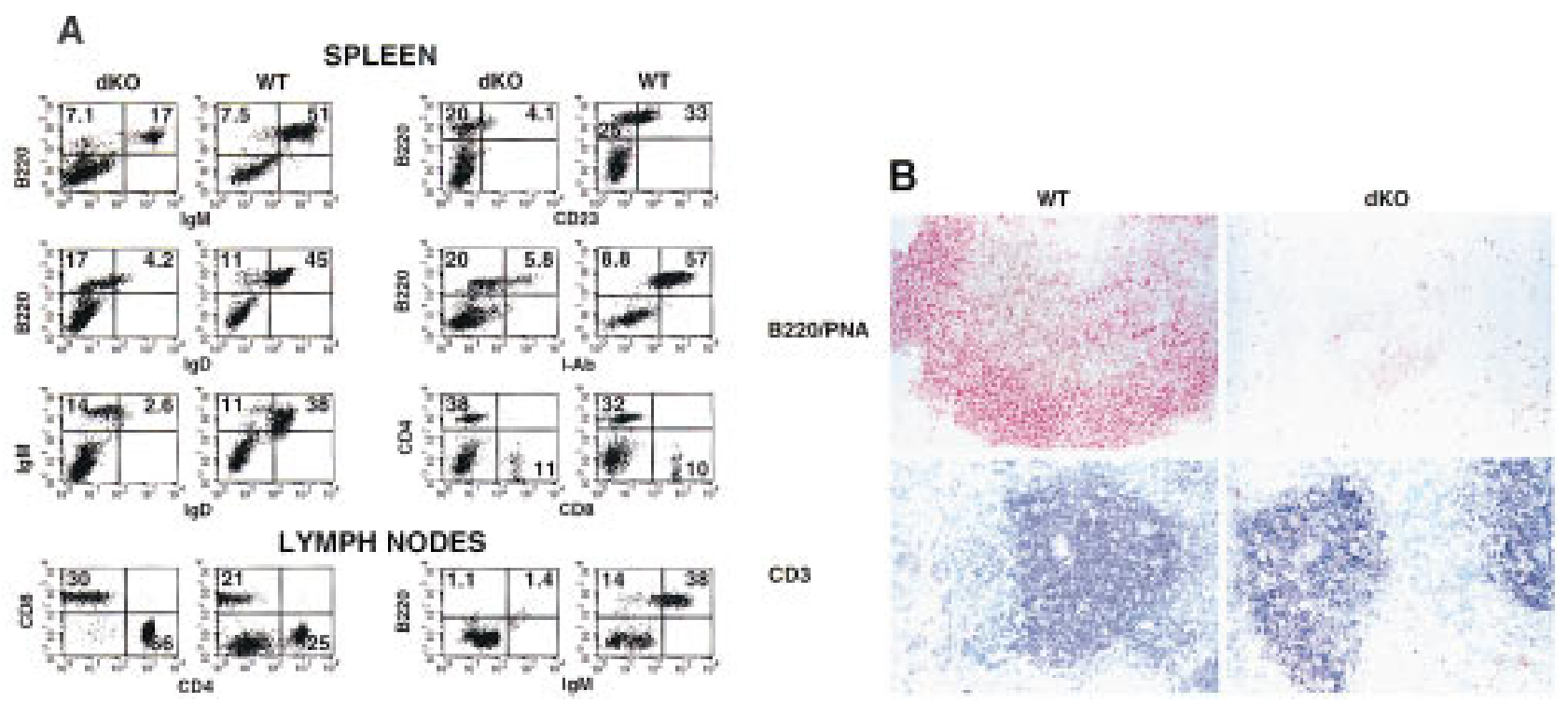

Figure 5. Developmental arrest of B cells is due to defects that track with to the B-cell lineage. Lethally irradiated RAG-1-deficient mice were injected with BM cells isolated from 22-day-ol d double knockout mice (dKO) or p50 $(+/+)$, p52 $(+/ \rightarrow)$ or p50 $(+/-)$, p52 $(+/+)(W T$; these mice are indistinguishable from wild type) littermate control donor mice, as indicated. Fifteen weeks later mice were chal lenged i.p. with TN P-KLH $(100 \mu \mathrm{g})$ adsorbed to al um. Mice were analyzed 9-days after challenge. (A) Three-color FCM anal ysis of spleen and Iymph nodes of adoptively transferred RAG-1-deficient mice. Two-color profiles or single-color histograms are displayed in black and white, and genotypes of donor animals are as indicated. The following antibodies (listed top to bottom and left to right) were used. Spleen: IgM-biotin vs. B220-PE; IgD-FITC vs. B220-PE; IgD-FITC vs. IgM-biotin; CD23-PE vs. B220-biotin; I-A ${ }^{\text {b}-b i o t i n ~ v s . ~ B 220-P E, ~}$ and CD4-biotin vs. CD 8a-PE. Lymph nodes: CD4-biotin vs. CD8a-PE and IgM-biotin vs. B220-PE. N umbers in the quadrants reflect the percentage of total spleen and lymph node cells in that quadrant. FCM data are representative of three paired sets of adoptively transferred RAG-1 mice. (B) Stained cryosections from representative double knockout (dKO, right panels) and p50( $+/-)$, p52( $+/+)(\mathrm{WT}$, left panels) control littermate marrow-transferred RAG-1-deficient animals are shown. Splenic cryosections were stained with PNA (brown) and anti-B220 antibodies (red) (top panels) or anti-CD-3 antibodies (blue; bottom panels), as indicated.

relative decrease in $\mathrm{CD} 4^{+}$and $\mathrm{CD} 8^{+}$single-positive $\mathrm{T}$ cells in mutant mice, although the extent of this decrease varied somewhat with age and among individual mice (Fig. 6B). We al so noted a relative reduction in the population of dull-staining double-positive $T$ cells (CD4 $4^{\text {dull }}$ CD $8^{\text {dull }}$ ) (Fig. 6B) and less intense staining for TCR, CD5, and CD69 in these thymocytes (data not shown), suggesting that positive selection may be partially impaired (Robey and Fowlkes 1994; Jameson et al. 1995; A nderson et al. 1996). Consistent with this and the exceedingly low absolute numbers of single-positive $T$ cells present in thymus glands, we detected almost no peripheral T cells in double knockout mice, as determined by FCM analysis of spleens or blood (Fig. 3, spleen, right panels; Thy1.2, CD4, and CD 8 markers) or by immunohistochemical analysis of spleen (Fig. 4B, CD3 marker).

As noted, adoptive transfers of double knockout BM cell $\mathrm{s}$ fai led to generate mature $B$ cells, but they generated abundant amounts of $\mathrm{CD} 4^{+}$and $\mathrm{CD} 8^{+} \mathrm{T}$ cells in spleen and lymph nodes of RAG-1 mice (Fig. 5A, FCM for CD 4 and CD 8; Fig. 5B, immunohistochemistry for CD3). This finding argues agai nst the notion that devel opmental defects intrinsic to T cells might have been responsible for lack of peripheral T cells in double knockout mice. $\mathrm{N} \mathrm{ev}$ erthel ess, it remains to be determined whether differentiated functions of doubl e knockout T cells are defective.

Medullary structures of the thymus appeared profoundly defective in double knockout mice (Fig. 6C, HE staining). Although thymic medullary DCs were detected by immunohistochemical analysis [Fig. 7A, M 342 marker (A gger et al. 1992)], they were not as clearly organized as those seen in control littermates and appeared to be reduced in numbers. Furthermore, mutant mice completely lacked medullary epithelial cells (MECs), as determined by staining with Ulex europaeus lectin (UEA-1) (Farr and Anderson 1985; Surh et al. 1992) and 4F1 antibodies (Kampinga et al. 1989) (Fig. 7A). Furthermore, the intense medullary staining for $\mathrm{I}-\mathrm{A}^{\mathrm{b}}$ seen in control littermates was absent in double knockout mice. $\mathrm{MHC}$ class II is known to be highly expressed in wild-type MECs and thymic medullary DCs (Burkly et al. 1995; Laufer et al. 1996). This suggests that the thymic DCs of mutant mice express less $1-A^{b}$, reflecting perhaps a functional impairment of these cells (see also below). In contrast to MECs, thymic cortical epithelial cells (CECs) were present in double knockout mice (Fig. 7A), although they were more randomly distributed, in line with the loss of 
A
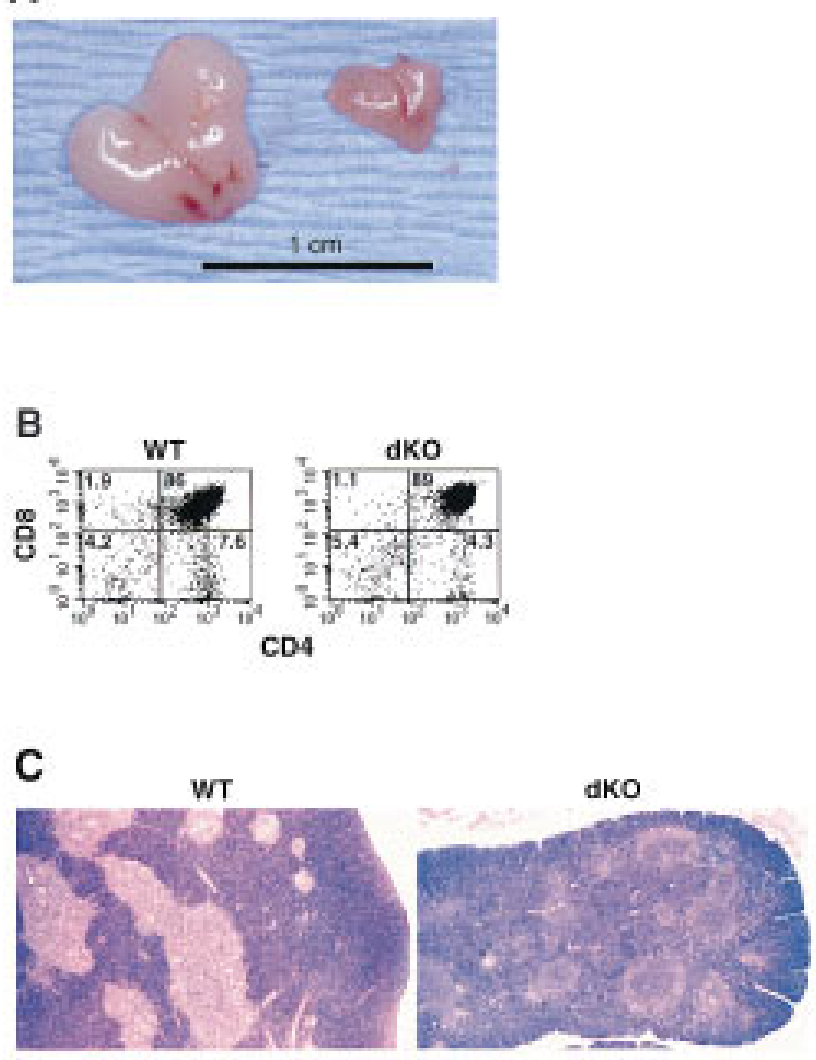

Figure 6. Impaired thymus glands in double knockout mice. (A) Macroscopic appearance of thymic glands obtained from a pair of 17-day-old littermates: (right) double knockout; (left) p50 $(+H)$, p52 $(H-)$. Original magnification was $1.3 \times$ The dKO thymus shown is one of the larger ones seen in mutant mice. (B) FCM analysis of a thymic cell suspension from a 5-day-old double knockout mouse (dKO, right panel) and a littermate control (p50 $(++)$, p52(H-); WT, left panel). CD4-biotin vs. CD8aPE two-color profiles are displayed. Results were confirmed with two additional pairs of mice. Numbers in the quadrants reflect the percentage of total cells in that quadrant. (C) Altered microarchitecture in thymic glands of double knockout mice. Representative, Bouin's-fixed paraffin-embedded sections were obtained from thymic glands of a 10-day-old double knockout mouse (dKO, right) and a wild-type littermate control (WT, left) and stained with $\mathrm{HE}$, as indicated.

the thymic architecture. Thus, p50 and/or p52 are required for normal thymic architecture (in addition to splenic architecture), possibly by contributing to the development, differentiation, and/or localization of MECs and DCs.

We observed a nearly complete lack of RelB and c-Rel protein in thymus extracts of double knockout mice, whereas expression of p65 was near normal (Fig. 7B, thymus). We also observed a roughly corresponding decrease in mRNA levels as judged by preliminary RT-PCR assays (data not shown). High levels of RelB in wild-type animal s have been reported for DCs (C arrasco et al . 1993) and for MECs (Burkly et al . 1995) and high level s of c-Rel have been noted in MECs (C arrasco et al. 1994). The lack of c-Rel is consistent with loss of MECs, whereas lack of RelB may reflect a loss of MECs and a defect in the reduced number of thymic DCs present (see above). Expression of RelB was also nearly undetectable in splenic extracts of double knockout mice and c-Rel was markedly reduced, whereas p65 was near normal (Fig. 7B, spleen). In wild-type spleen, high levels of RelB have been associated primarily with DCs (Carrasco et al.
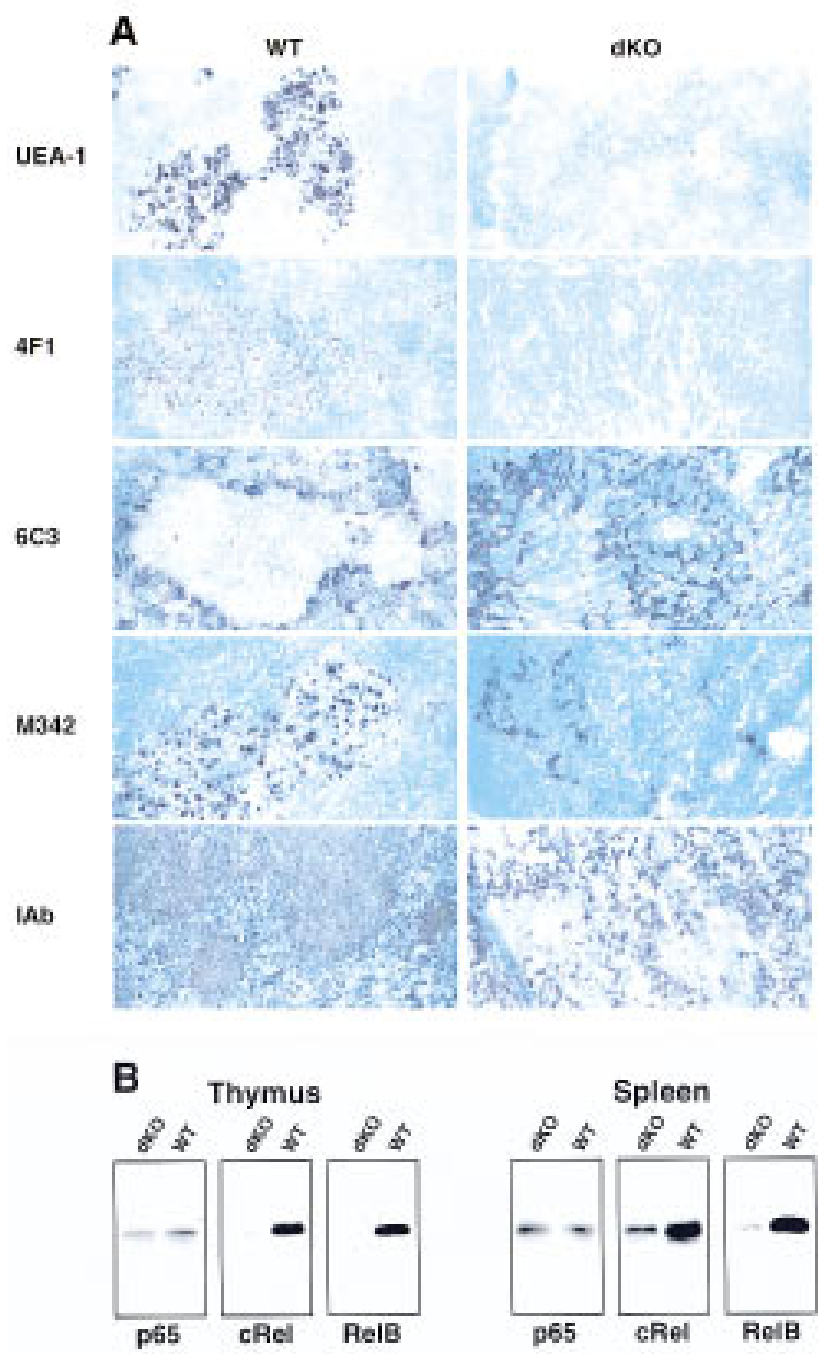

Figure 7. Histologic abnormalities in thymus glands of double knockout mice. (A) Thymic glands were obtained from 15- to 17-day-old double knockout mice (dKO, right) and littermate controls [WT, left; all controls were p50 $(+/+)$, p52 $(+/-)$, except for the I-A $\mathrm{A}^{\mathrm{b}}$ staining where the genotype of the control mouse was $\mathrm{p} 50(+/-), \mathrm{p} 52(+/+)]$. Acetone-fixed, frozen sections were processed with UEA-1 (staining MECs) or anti-MEC (4F1), anticortical ephitelial cell (6C3), anti-dendritic cell (M342), and anti-class II (I-A ${ }^{\text {b }}$ ) antibodies, as indicated. Stained cryosections from representative pairs of littermates are shown. (B) Reduced expression of RelB and C-Rel in spleens and thymus glands of double knockout mice. Western blot analyses of thymus glands (left panels) and spleens (right panels) from 13-day-old double knockout (dKO) and control littermates [WT, p50( $+/+)$, p52 $(+/$ $-)$ ] mice are shown. Antibodies to various N F-кB family members were used as indicated. 
1993) and folicular dendritic cells (FDCs) (Feuillard et al. 1996), whereas high levels of c-Rel have been associated with FDCs (Feuillard et al. 1996) and mature B cells (Liou et al 1994; Miyamoto et al. 1994). The results with double knockout splenic extracts are therefore consistent with loss of FDCs [previously noted in p52-deficient mice (Franzoso et al. 1998] and lack of mature B cells, and they suggest potential defects in splenic DCs as well, in line with the immunohistochemical analysis.

\section{Discussion}

The present study demonstrates that NF-кB transcription factors carry out essential functions in development. Mice lacking both the p50 and p52 subunits of NF-kB have arrested development of osteoclasts and B cells. The defects appear to track with the affected hematopoi etic lineages, as demonstrated by adoptive transfer experiments. Mice deficient in either the p50 or p52 subunit did not present with such defects (Sha et al. 1995; Franzoso et al. 1998), implying redundant functions of these two highly homologous subunits in development of cell lineages. The role of N F-kB in osteoclast formation was unanticipated, and a role in B cell maturation had not been shown previously. As a consequence of the osteoclast deficiency, double knockout mice developed osteopetrosis and succumbed within 3-4 weeks of birth.

Loss of both p50 and p52 profoundly reduces the repertoire of NF-кB dimers available in mutant mice. In addition to forming homodimers, which have diverse functions (Franzoso et al. 1992, 1993; Bours et al. 1993; Fujita et al. 1993), these two subunits are usually the primary partners for p65 and c-Rel and likely the exclusive partners for RelB. The only complexes that form in the absence of $p 50$ and $p 52$ are homo- or heterodimers of p65 and c-Rel, which normally represent only a minor proportion of DNA-binding NF-KB complexes (for review, see Baeuerle and Henkel 1994; Siebenlist et al. 1994; Verma et al. 1995; Baldwin 1996) and are present in mutant stimulated splenocytes at levels not dramatically different from those of control cells (save for some reduction of c-Rel complexes because of partial loss of c-Rel protein), at least as judged by el ectrophoretic mobility shift assays (data not shown). Double knockout mice also lack the precursor forms of the p50 and p52 proteins (p105 and p100, respectively), which contain IкB-like domains and are retained in the cytoplasm until processed (see Baeuerle and Henkel 1994; Siebenlist et al . 1994; Verma et al. 1995; Bal dwin 1996).

\section{Impaired osteoclast devel opment}

Osteopetrosis, a disease characterized by impaired bone resorption (Popoff and M arks 1995), can result from defects in the bone-forming stromal osteoblasts that are required for osteoclast formation or from defects in the osteoclast lineage itself ( $Y$ oshida et al. 1990; Soriano et al. 1991; Takahashi et al. 1991; Wang et al. 1992; Grigoriades et al. 1994; Tondravi et al. 1997). A doptively transferred hematopoietic precursors from wild-type mice rescued osteopetrosis in double knockout mice, implying that these mice harbored a defect that tracked with the osteoclast lineage rather than with the osteoblast lineage, because the latter cells were not transferred (Lowe et al. 1993). In vitro coculture experiments supported this conclusion: Mature osteoclasts could not be generated from splenic precursors of double knockout mice, even when cocultured with wild-type osteoblasts (see Fig. 2A). Furthermore, histochemical staining for TRAP activity demonstrated that mature multinucleated osteoclasts as well as their immediate mononuclear precursors were absent from bones of double knockout mice. Therefore, the block in osteoclast development occurs prior to the appearance of TRAP-positive mononuclear cells.

Recent studies have shown that N F-кB inhibitors can induce apoptosis of mature osteocl asts and inhibit bone resorption by isolated osteoclasts (Ozaki et al. 1997). However, we found no clear evidence that the failure of osteoclast formation in double knockout mice was due to increased apoptosis of these cells or their precursors. Although it is possible that there was increased apoptosis of TRA ${ }^{-}$osteoclast mononucl ear precursors, we saw no obvious evidence of this in bone sections of the double knockout mice.

Development along the macrophage/osteoclast lineage requires the activity of transcriptonal factors, PU.1 and C-Fos, as well as production of M-CSF by stromal cells. PU.1 knockout mice have cell-autonomous defects in the myeloid/monocyte lineage. They do not form osteoclasts or macrophages and devel op severe osteopetrosis (Tondravi et al. 1997). op/op mice, which lack functional M-CSF (Yoshida et al. 1990; Takahashi et al. 1991), and c-Fos knockout mice al so fail to generate osteoclasts and become osteopetrotic, but these animals produce macrophages (Felix et al. 1990; Wang et al. 1992; Grigoriades et al . 1994), suggesting that c-Fos and M-CSF are required for commitment to the osteoclast lineage. Osteopetrosis also occurs in c-Src knockout mice (Soriano et al. 1991), but here osteoclast function, rather than development, is impai red (Boyce et al. 1992). In our mutant mice, $\mathrm{Mac}-\mathrm{I}^{+}$and $\mathrm{F} 4 / 80^{+}$mature macrophages were detected in both liver and spleen, although differentiated functions of peritoneal macrophages were impaired (see below). While the precise role for N F-KB factors in formation and function of the various tissue macrophages remains to be determined, a PU.1-like defect in an early multipotential precursor is rul ed out. N F-кB factors may be required as early as the point of commitment to the osteoclast lineage or as late as the mitotic phase, which occurs just prior to generation of postmitotic TRAP ${ }^{+}$ mononuclear osteoclasts (Fig. 8).

M acrophages of double knockout mice were functionally impaired. Thioglycollateelicited, mutant macrophages failed to respond normally to LPS. Induction of several cytokine mRN As appeared to be altered and, in a 


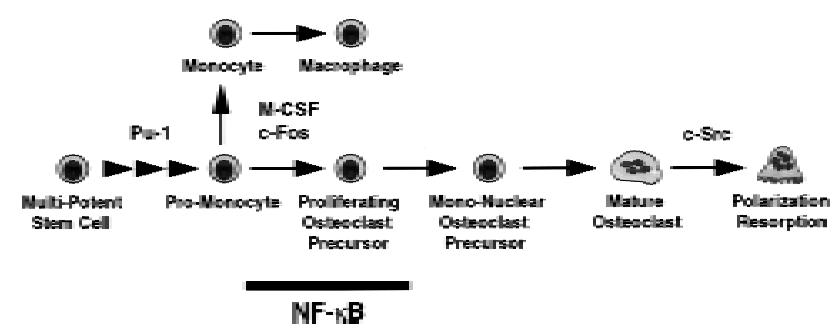

Figure 8. Model for osteoclast devel opment indicating stage at which N F-kB appears to be required (see text).

few cases, dramatically so (decrease in GM-CSF and GCSF, and increase in IFN - $\beta$ ). Increased IFN - $\beta$ production has been noted previously in virally challenged p50 knockout mice, possibly because of the release from the transcriptional repression exercised by p50 homodimers on this gene (Sha et al. 1995; Franzoso et al. 1992, 1993). An equally complex, but different, pattern of altered cytokine regulation has been observed previously in c-Rel knockout mice (Kontgen et al. 1995; Gerondakis et al. 1996; Grigoriadis et al. 1996). Together, these and our findings reveal intricate gene-specific uses of N F-кB factors in both positive and negative transcriptional regulation.

Discovery of the role of NF-кB in osteoclast development may open up new avenues for investigation of the pathogenesis and treatment of postmenopausal osteoporosis, the most common bone disease in the developed world (Melton 1995), in which bone is lost due to increased resorbing activities of osteoclasts (Horowitz 1993). Recent studies suggest that the increased activity of osteocl asts is mediated by cytokines interleukin-1 (IL1), IL-6, TNF, and GM-CSF (Pacifici et al. 1991; Jilka et al. 1992; Kitazawa et al . 1994; Jimi et al. 1995; Kimble et al. 1995). These cytokines are known transcri ptional targets of NF-кB in differentiated cells and are induced to high levels during inflammatory reactions; however, with the exception of IL-6, these cytokines are al so potent activators of NF-кB (Baeuerle and Henkel 1994; Si ebenlist et al. 1994; Verma et al. 1995; Baldwin 1996), and as such they may stimulate osteoclast formation and survival (E. Jimi, I. Nakamura, T. Ikeber, N. Takahashi, and T. Suda, unpubl.). Therefore, these studies, together with our findings, implicate NF-кB and cytokines in both the formation of osteoclasts and in the regulation of their activity, particularly under conditions such as postmenopausal osteoporosis and rheumatoid arthritis, in which increased production of cytokines is associated with bone loss. Consequently, N F-кB may provide a new multifunctional target for therapeutic intervention to reduce abnormally high bone-resorbing activity in human diseases.

\section{Impaired B-cell development}

Loss of p50 and p52 al so blocks B-cell development, with cells of this lineage progressing only to an immature stage $\left(C D 19^{+}, \mathrm{IgM}^{+}, \mathrm{B} 220^{\text {dull }}, \mathrm{CD}^{2} 3^{-}, \mathrm{IA}^{\mathrm{b} \text { dull }}, \mathrm{CD} 23^{-}\right.$, IgD -), devoid in expression of any mature B-cell markers (such as CD23, IgD, B220 bright, IA b bright; for review, see Rajewsky 1996; Duchosal 1997; Melchers 1997). Whether loss of p50 and p52 affects progression of B cells through earlier stages of development (without blocking it) remains to be explored. Previous studies of mice deficient in various subunits of NF-kB did not uncover an involvement of this transcription factor in maturation of $B$ cells. However, such a role is consistent with the observation that only mature $B$ cells contain constitutive N F-kB activity, whereas primary pre-B/immature B cells do not (Liou et al. 1994; Miyamoto et al. 1994). The constitutive activity consists primarily of c-Rel/p50 complexes, in line with increased levels of expression of cRel in these cells. In agreement with the lack of mature $B$ cells in double knockout mice, c-Rel expression in total spleen extracts was markedly reduced. Although little is known about the transition of B cells from an immature to a mature stage, it has been speculated that positive selection occurs, as only few of the numerous, short-lived immature BM B cells are rescued to become longer-lived mature, peripheral B cells (Rajewsky 1996; Duchosal 1997; Melchers 1997). The transition may involve the B-cell receptor-associated Syk kinase (T urner et al. 1995), and maintenance of mature B cells, if not also their generation from immature cells, has been shown to require a functional B-cell receptor (Lam et al. 1997). p50- and p52-containing N F-кB factors could play a direct role in the transition/mai ntenance and rescue of $B$ cells to become longer-lived cells, consistent with demonstrated anti-apoptotic functions of NF-кB (Beg and Baltimore 1996; Liu et al. 1996; Van Antwerp et al. 1996; Wang et al. 1996; Wu et al. 1996). Alternatively, they could play an indirect role, for example, by regulating proper homing of, or signaling within, maturing cells.

In contrast to the critical roles of p50- and p52-containing NF-кB factors in generation of mature B cells, these factors are not absolutely required for expression of $\kappa$ light chains. A requisite role for N F- $\kappa B$ factors in expression and/or rearrangement of the $\kappa$ locus has been proposed based on ex vivo studies (Kirillov et al. 1996; Scherer et al. 1996; see also Shaffer et al. 1997). It is possible that p65 and c-Rel complexes that remain present in p50 and p52 double knockout mice are sufficient to execute this function.

The developmental defect of double knockout B cells appears to track with this lineage, as indicated by failure of mutant stem cell precursors to fully mature, even on a RA G-1 mouse background. Recipi ent RAG-1 mice contained only immature double knockout B cells, which were present in spleen but were unable to populate Iymph nodes. In contrast, adoptively transferred RAG-1 mice readily supported the generation of double knockout $T$ cells, as judged by the abundance of single-positive (CD4 or CD8), $C D 3^{+} \mathrm{T}$ cells in both spleen and Iymph nodes of these mice. It is worth noting that whereas the adoptive transfer experiments clearly suggest defects lying within the osteoclast and B-cell lineages, it remains theoretically possible that other hematopoietic cells are required for devel opment of these lineages and are defective, al though no such cells are known to exist. Our ex- 
periments furthermore do not address whether the defects are cell autonomous or not, because even if the primary defect lay within the B-cell lineage, for example, it may or may not involve defective production of a Bcell lineage-derived extracellular-acting factor required to promote further B-cell devel opment, acting di rectly or indirectly.

\section{Impaired thymic and splenic microarchitecture}

The splenic white pulp is missing and the thymic medulla is disrupted in double knockout mice. Thymic MEC s are absent, and both thymic and splenic DCs appear to be functionally impaired, specific defects that resemble those noted in RelB-deficient mice (Burkly et al. 1995; Weih et al. 1995; DeKoning et al. 1997) but not in p50- or p52-deficient mice. In support of the notion that a defect common to both the double knockout and RelB-deficient mice may be responsible for some shared thymic and splenic abnormalities, RelB function may be completely deficient in double knockout mice, as p50 and p52 are the only known dimeric partners of RelB. Beyond this, expression of RelB was extremely low in extracts of double knockout thymus glands or spleen. Lack of RelB is explained in part by loss of RelB-containing cell types, but in addition, the data imply a defect in the reduced number of double knockout DCs that were present, as such cells normally produce high levels of this protein. Thus, it is possible that expression of RelB in DCs depends on p50- and p52-containing complexes.

Although adoptive transfers of wild-type fetal liver or BM rescued the osteopetrotic phenotype, they did not change the small size of the thymus or the impaired architecture of thymus and spleen. Although the time between adoptive transfer and sacrifice may have been too short to observe rescue, some defects may not be rescued using this approach, because they may lie in nonhematopoi etic cells, such as M ECs. It is also possi ble that rescue requires the presence of wild-type cells during an early phase of development, a phase that had been completed prior to transfer. In any case, the thymic impairment is not likely to be due to defects intrinsic to $T$ cells, because adoptive transfers of double knockout BM into RAG-1-deficient mice generated apparently mature $\mathrm{T}$ cells from mutant precursors. Consequently, lack of peripheral $\mathrm{T}$ cells in double knockout mice may simply reflect the low absolute numbers of single-positive thymic cells and the short time for accumulation prior to sacrifice.

Altogether, the results presented with p50 and p52 double knockout mice reveal an extensive and complex invol vement of N F-кB factors in development and function of hematopoi etic cells and generation of Iymphoid organ architecture. N F-кB factors are thus central to the establishment and responses of the host defense system, perhaps reflecting an intricate, underlying regulatory network. Generation of mice lacking other combinations of NF-кB factors may reveal yet more critical roles of this transcription factor family, especially in development, where utilization of redundant functions of the various factors may be the rule rather than the exception.

\section{Materials and methods}

Generation of p52/p100-deficient mice

p52/p100-deficient mice were generated in a manner anal ogous to that described previously for Bcl-3 knockout mice (Franzoso et al. 1997), as described in detail elsewhere (Franzoso et al. 1998). As a result of the del etion of the exons encoding the p52 dimerization domain and the first seven ankyrin repeats of the p100 precursor, homozygous mice lacked expression of functional protein.

Preparation and staining of bone sections

Bones (calvariae, fore- and hindlimbs, and lumbar vertebrae) were fixed in 10\% buffered formal in, decal cified in 10\% EDTA, and embedded in paraffin. Sections ( $4 \mu \mathrm{m}$ thick) were then stained either with HE or for TRAP activity, as described previously (Hughes et al. 1996).

\section{Generation of osteoclasts in coculture experiments}

Primary osteoblasts were isolated from calvariae of 3- to 5-dayold mice using a sequential collagenase/protease digestion (Lowe et al. 1993). Primary osteoblasts ( $10^{4}$ cells/well) and spleen cells $\left(5 \times 10^{5}\right.$ cells/well) from either wild-type or p50 $(-1$ $\rightarrow$ p52 $(-1-)$ mutant mice were cocultured on dentine slides in 48-well plates for 20 days in $\alpha$-minimum essential medium containing $10 \%$ fetal calf serum (FCS) and $10^{-8} \mathrm{M} 1,25$ dihydroxyvitamin $D_{3}$. Cells on dentine slides were then fixed in culture wells with $3 \%$ paraformaldehyde and $2 \%$ sucrose and stained for TRAP activity (Lowe et al. 1993). TRAP ${ }^{+}$cells containing three or more nuclei were counted as osteoclasts. After counting, cells were removed and the number of resoption pits formed quantified as described previously (Lowe et al. 1993).

Fetal liver adoptive transfer

Liver cell suspensions were prepared from 14-day wild-type embryos. Cells were then injected intraperitoneally (i.p.) into 4day-old double knockout and wild-type control animals that had been lethally irradiated (800 rads) $24 \mathrm{hr}$ earlier (see Soriano et al. 1991). Bones were collected and anal yzed 3-4 weeks after the transfer. As discussed in the text, recipient double knockout mice were rescued from osteopetrosis, and recipient controls showed no obvious deterioration as a result of the procedure.

\section{Bone marrow adoptive transfer}

Bone marrow cells $\left(10^{7}\right)$, isolated from femora of 22-day-old p50 $(-1-)$ p52 $(-t-)$ double knockout or p50 $(++)$ p52 $(+t-)$ (indistinguishable from wild type) donor mice were injected intravenously into RAG-1 mice (Jackson Laboratory) that had been lethal ly irradiated at 900 rads $24 \mathrm{hr}$ earlier. Fifteen weeks later, adoptively transferred RAG-1 mice were injected i.p. with TNP-KLH (100 $\mu \mathrm{g})$ adsorbed to al um. For cryosections, spleens and lymph nodes were collected 9 days after injection.

Preparation of TNP conjugates

TNP-KLH was prepared as described previously (Franzoso et al. 1998). Briefly, 20 mg of Iyophilized KLH (Pierce Chemical Co.) 
was dissolved in $4 \mathrm{ml}$ of potassium borate buffer $(0.25 \mathrm{M}$ at $\mathrm{pH}$ 9.2), and $3 \mathrm{mg}$ of TNBS (2,4,6-trinitro-benzyl sulfonic acid, Sigma Chemical Co.) was added along with $16 \mu$ of sodium carbonate $(1 \mathrm{M})$. The reaction was allowed to take place overnight, after which the protein derivatives were dialyzed against PBS (pH 7.4). TNP-KLH conjugates were frozen at $-20^{\circ} \mathrm{C}$ until use.

Preparation and culture of thioglycollate-elicited peritoneal macrophages

M ice were sacrificed 5 days after i.p. injection of $1 \mathrm{ml}$ of a $2.95 \%$ thioglycollate solution in water. Peritoneal exudate cells were harvested by washing the peritoneal cavity with $2 \mathrm{ml}$ of cold RPMI medium supplemented with $2 \%$ FCS (Hyclone), $\beta$-mercaptoethanol $(50 \mathrm{~mm})$, penicillin $\mathrm{G}(100 \mathrm{U} / \mathrm{ml})$, and streptomycin $(100 \mu \mathrm{g} / \mathrm{ml})$. Cells were then incubated in 24-well plates $\left(10^{6} /\right.$ well $)$ at $37^{\circ} \mathrm{C}$ for $2 \mathrm{hr}$. N onadherent cells were removed by washing with complete RPM I medium, and the remaining cells treated with $50 \mu \mathrm{g} / \mathrm{ml}$ of LPS (Escherichia coli serotype 0111:B4, Sigma Chemical Co.) or left untreated for an additional $2 \mathrm{hr}$ before harvesting.

\section{RT-PCR analysis of gene expression}

RN A was isolated from adherent thioglycollate-elicited macrophages obtained as described above. The peritoneal exudates were analyzed by FCM analysis and found to be similar for wild-type and double knockout mice (not shown). RNA was isolated from the adherent monolayer of thioglycollate-elicited peritoneal macrophages with or without stimulation of LPS by using Trizol reagent (GIBCO BRL), as instructed by the manufacturer. CDNA synthesis was performed in $25 \mu \mathrm{l}$ from $1 \mu \mathrm{g}$ of total RNA using the Superscript II Moloney murine leukemia virus reverse transcriptase (GIBCO BRL) and random primers (Promega). The amount of $0.1-2 \mu l$ of the cDNA product was amplified with the Amplitaq DNA polymerase (Perkin Elmer) in $50 \mu \mathrm{l}$, and conditions were experimentally assessed for each pair of primers to allow for an analysis in the exponential range. The annealing temperature was $62^{\circ} \mathrm{C}$, except for G-CSF $\left(56^{\circ} \mathrm{C}\right.$ ) and IFN- $\gamma\left(58^{\circ} \mathrm{C}\right)$; and the $\mathrm{MgCl}_{2}$ concentration was $1.5 \mathrm{~mm}$, except for G-CSF and GM-CSF (2 mM), and IL-1 $\beta$ ( $2.8 \mathrm{~mm})$. The number of cycles varied between 30 and 35 (21 cycles for GAPDH). The following primers were used: G-CSF (5'CCAACTTTGCCACCACCATCTG-3' and 5'-GGAGCAGCAGCAGGAATCAATA-3'); GM-CSF (5'-TGTGGTCTACAGCCTCTCAGCAC-3' and 5'-CAAAGGGGATATCAGTCAGAAAGGT-3'); M-CSF (5'-CAGATCAAGGAAGACAACCG-3' and 5'-ATGGTACATCCACGCTGCGT-3'); TNF- $\alpha$ (5'-ATGAGCACAGAAAGCATGATCCGC-3' and 5'-CCAAAGTAGACCTGCCCGGACTC-3'); IL-6 (5'-ATGAAGTTCCTCTCTGCAAGAGACT-3' and 5'-CACTAGGTTTGCCGAGTAGATCTC-3'); IFN - $\beta$ (5'-CTCCAGCTCCAAGAAAGGACG-3' and 5'-GAAGTTTCTGGTAAGTCTTCG-3'); IFN- $\gamma$ (5'-GACTTCAAAGAGTCTGAGG-3' and 5'-AACGCTACACACTGCATCTTGG-3'); TNF- $\beta$ (5'-TGACACTGCTCGGCCGTCTCCA-3' and 5'-GTTGCTCAAAGAGAAGCCATGTCG3'); IL-12/p40 (5'-CGTGCTCATGGCTGGTGCAAAG-3' and 5'GAACACATGCCCACTTGCTG-3'); IL-12/p35 (5'-GGCTACTAGAGAGACTTCTTCC- $3^{\prime}$ and 5'-GTGAAGCAGGATGCAGAGCTTC-3'); IL-10 (5'-CACTACCAAAGCCACAAAGC-3' and $5^{\prime}$-CATGGCCTTGTAGACACCTT-3'); IL- $1 \alpha$ (5'-ATGGCCAAAGTTCCTGACTTGTTT-3' and 5'-CCTTCAGCAACACGGGCTGGTC-3'); IL-1ß (5'-ATGGCAACTGTTCCTGAACTCAACT-3' and '5'-CAGGACAGGTATAGATTCTTTCCTTT3'); i-NOS (5'-CAAAGTCAAATCCTACCAAAGTGACCTG-3' and 5'-TGCTACAGTTCCGAGCGTCAAAGACCTG-3'); GAPDH(5'-GGTGAAGGTCGGTGTGAACGGA-3' and 5'-TGTTAGTGGGGTCTCGCTCCTG-3').

\section{FCM analysis}

Three-color FCM analysis of single cell suspensions of spleen, lymph nodes, and BM was performed with the following antibodies: anti-B220-phycoerythrin (PE), anti-M ac-1-PE, antiCD8a-PE, anti-CD23-PE, anti-B220-fluorescein isothiocyanate (FITC), anti-IgD-FITC, anti-CD23-FITC, Gr-1-FITC, anti-кlight chain (LC)-FITC, anti- $\lambda$-LC-FITC, anti-B220-biotin, anti-

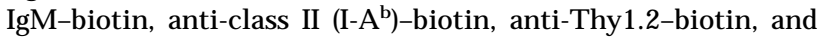
anti-CD4-biotin; the biotin-conjugated antibodies were followed by addition of streptavidin-Red 670 (GIBCO BRL), as described previously (Shores et al. 1994). All antibodies were purchased from Pharmingen, except for the anti- $\kappa-L C$ and anti- $\lambda-$ LC antibodies, which were obtained from Southern Biotechnology.

\section{HE staining of paraffin-embedded tissues}

Spleens and thymic glands were fixed in Bouin's fixative for 24 $\mathrm{hr}$, rinsed, and transferred into $70 \%$ ethanol. Tissues were then processed through alcohol and xylene, embedded in paraffin, sectioned at $5 \mu \mathrm{m}$, and stained with $\mathrm{HE}$.

\section{Immunoperoxidase staining of frozen sections}

Spleens and thymic gl ands were extracted, placed in OCT freezing medium (Miles Laboratories Inc.), and flash frozen. Ten micrometers of acetone-fixed sections were stained as described previously (Franzoso et al. 1997). Briefly, tissue sections were rehydrated in PBS containing $0.1 \%$ BSA (fraction V, PBS/BSA; Sigma Chemical Co.) and blocked for $30 \mathrm{~min}$ with $10 \mu \mathrm{g} / \mathrm{ml}$ of 2.4G2 antibody (anti-Fc receptor, Pharmingen) diluted in Dako antibody diluent (Dako Corporation) for staining of spleen sections or with Dako protein block for staining of thymus sections. After blocking, sections were incubated for $60 \mathrm{~min}$ with the primary antibody prepared in Dako antibody diluent, washed in PBS/BSA, and incubated for additional $30 \mathrm{~min}$ with the biotinylated secondary antibody in Dako antibody diluent (except for those stained with biotin- and HRP-conjugated antibodies and with HRP-conjugated UEA-1). After quenching endogenous peroxidase activity, tissue sections were incubated for 30 min with streptavidin-conjugated HRP (Vector Laboratories), except for the CD45RB/B220 staining where the secondary antibody was alkaline phosphatase (AP)-conjugated (see below). Slides were then washed in PBS/BSA, and the avidin/biotin complexes revealed with the DAB tetrahydrochloride chromogen (Vector Laboratories), according to the manufacturer's instructions. Finally, slides were rinsed, counterstained with methyl green (Vector Laboratories), and mounted with Permount (Fisher Scientific) (Franzoso et al. 1997). HRP-conjugated UEA-1 (Sigma Chemical Co) and the following primary antibodies were used: Mac-1 (anti-macrophages, BoehringerMannheim), M 342 (anti-dendritic cells, a kind gift of Dr. B. Kel sal I, N ational Institutes of Health, Bethesda, MD), 4F1 (antithymic MECs, Biosource International), 6C3 (anti-thymic cortical epithelial cells, Pharmingen), anti-I-A ${ }^{b}$ (Pharmingen), biotinylated anti-CD45RB/B220 (Pharmingen), biotinylated anti-CD3 (Pharmingen), and biotinylated F4/80 (anti-macrophages, Caltag). 


\section{Double staining of frozen sections}

Double immunohistochemical staining was performed on acetone-fixed cryosections as described previously (Franzoso et al . 1998). Briefly, tissue sections were rehydrated in PBS/BSA, blocked for 20 min with Dako protein block, and subsequently incubated for $1 \mathrm{hr}$ with biotinylated anti-CD 45R/B220 antibodies (Pharmingen) followed by a 30-min incubation with APconjugated streptavidin (Vector Laboratories). Sections were then incubated for $1 \mathrm{hr}$ with HRP-conjugated PNA (Dako Corporation), and endogenous peroxidase activity quenched with $1 \% \mathrm{H}_{2} \mathrm{O}_{2}$ in PBS for $15 \mathrm{~min}$. Washings were as described above. AP and HRP enzymatic activities were finally reveal ed with the Fast Red (Dako Corporation) and DAB (Vector Laboratories) chromogens, respectively, and specimens mounted in aqueous mounting medium (Dako Corporation).

\section{Western blot and antibodies}

Whole-cell extracts were prepared as described previously (Dignam et al. 1983) and proteins separated by SDS-PAGE. Proteins were then blotted onto Immobilon-P membranes (Millipore) and analyzed by the ECL Western blotting detection system (Amersham), as instructed by the manufacturer. The antibodies used were a rabbit anti-peptide antibody directed to the amino terminus of human p65 (Franzoso et al. 1992), a commercial rabbit antibody recognizing amino acids 152-176 of murine cRel (Santa Cruz) and a commercial rabbit anti-murine Rel-B carboxy-terminal peptide antibody (Santa Cruz).

\section{Acknowledgments}

We thank K. Kelly for review of the manuscript and A.S. Fauci for continued support. We are grateful to W. Sha and D. Baltimore for the $\mathrm{p} 50(-1-)$ mice, B. Kelsall for the M 342 antibody, B. Story and A. Farias for technical assistance with bone histology, R. Germain for discussion, P. Schwartzberg for hel pful advice, and $M$. Rust for help with the preparation of this manuscript. This project was partly funded by a grant from the $\mathrm{N}$ ational Institutes of Health (AR-43510 to B.F.B.).

The publication costs of this article were defrayed in part by payment of page charges. This article must therefore be hereby marked "advertisement" in accordance with 18 USC section 1734 solely to indicate this fact.

\section{References}

Agger, R., M. Witmer-Pack, N. Romani, H. Stossel, W.J. Swiggard, J.P. Metlay, E. Storozynsky, P. Freimuth, and R.M. Steinman. 1992. Two populations of splenic dendritic cells detected with M342, a new monoclonal antibody to an intracellular antigen of interdigitating dendritic cells and some B lymphocytes. J. Leukocyte Biol. 52: 34-42.

Anderson, G., N.C. M oore, J.J. Owen, and E.J. Jenkinson. 1996. Cellular interactions in thymocyte development. Annu. Rev. Immunol. 14: 73-99.

Baeuerle, P.A. and T. Henkel. 1994. Function and activation of NF-kB in the immune system. Annu. Rev. Immunol. 12: 141-179.

Baldwin, A.S. 1996. The NF-kB and IкB proteins: New discoveries and insights. Annu. Rev. Immunol. 14: 649-681.

Beg, A.A. and D. Baltimore. 1996. An esssential role for N F-кB in preventing TNF- $\alpha$-induced cell death. Science 274: 782784.

Beg, A.A., W.C. Sha, R.T. Bronson, and D. Baltimore. 1995a. Constitutive NF-kB activation, enhanced granulopoiesis, and neonatal lethality in IкB $\alpha$-deficient mice. Genes $\&$ Dev. 9: 2736-2746.

Beg, A.A., W.C. Sha, R.T. Bronson, S. Ghosh, and D. Baltimore. 1995b. Embryonic lethality and liver degeneration in mice lacking the RelA component of N F-кB. Nature 376: 167-170.

Belvin, M.P. and K.V. Anderson. 1996. A conserved signaling pathway: The Drosophila toll-dorsal pathway. Annu. Rev. Cell. Dev. Biol. 12: 393-416.

Boothby, M.R., A.L. Mora, D.C. Scherer, J.A. Brockman, and D.W. Ballard. 1997. Perturbation of the T Iymphocyte lineage in transgenic mice expressing a constitutive respressor of nuclear factor (NF)-кB. J. Exp. Med. 185: 1897-1907.

Bours, V., G. Franzoso, V. Azarenko, S. Park, T. Kanno, K. Brown, and U. Siebenlist. 1993. The oncoprotein Bcl-3 directly transactivates through $1 \kappa B$ motifs via association with DNA-binding p50B homodimers. Cell 72: 729-739.

Boyce, B.F., T. Yoneda, C. Lowe, P. Soriano, and G.R. Mundy. 1992. Requirement of pp60c-scr expression for osteoclasts to form ruffled borders and resorb bone in mice. J. Clin. Invest. 90: 1622-1627.

Breel, M., R.E. M ebius, and G. Kraal. 1987. Dendritic cells of the mouse recognized by two monoclonal antibodies. Eur. J. Immunol. 17: 1555-1559.

Burkly, L., C. Hession, L. Ogata, C. Relly, L.A. Marconi, D. Olson, R. Tizard, R. Cate, and D. Lo. 1995. Expression of Rel $B$ is required for the development of thymic medulla and dendritic cells. Nature 373: 531-536.

Carrasco, D., R.P. Ryseck, and R. Bravo. 1993. Expression of relB transcripts during lymphoid organ devel opment: Specific expression in dendritic antigen-presenting cells. Development 118: 1221-1231.

Carrasco, D., F. Weih, and R. Bravo. 1994. Developmental expression of the mouse c-rel proto-oncogene in hematopoietic organs. Development 120: 2991-3004.

DeKoning, J., L. DiM olfetto, C. Reilly, Q. Wei, W.L. Havran, and D. Lo. 1997. Thymic cortical epithelium is sufficient for the development of mature $T$ cells in relB-deficient mice. J. Immunol. 158: 2558-2566.

Dignam, J.D., R.M. Lebovitz, and R.C. Roeder. 1983. Accurate transcription initiation by RNA polymerase II in a soluble extract from isolated mammalian nuclei. Nucleic Acids Res. 11: 1475-1489.

Doi, T.S., T. Takahashi, O. Taguchi, T. Azuma, and Y. Obata. 1997. NF-кB RelA-deficient lymphocytes: N ormal development of $T$ cells and B cells, impaired production of IgA and $\operatorname{lgG} 1$ and reduced proliferative responses. J. Exp. Med. 185: 953-961.

Duchosal, M.A. 1997. B-cell development and differentiation. Semin. Hematol. 34: 2-12.

Farr, A.G. and S.K. Anderson. 1985. Epithelial heterogeneity in the murine thymus: Fucose-specific lectins bind medullary epithelial cells. J. Immunol. 134: 2971-2977.

Felix, R., M.G. Cecchini, W. Hofstetter, P.R. Elford, A. Stutzer, and $\mathrm{H}$. Fleisch. 1990. Impairment of macrophage colonystimulating factor production and lack of resident bone marrow macrophages in the osteopetrotic op/op mouse. J. Bone Miner. Res. 5: 781-789.

Feuillard, J., M. Koerner, A. Israel, J. Vassy, and M. Raphael. 1996. Differential nuclear localization of p50, p52 and RelB proteins in human accessory cells of the immune response in situ. Eur. J. Immunol. 26: 2547-2551.

Franzoso, G., V. Bours, S. Park, M. Tomita-Yamaguchi, K. Kelly, and U. Siebenlist. 1992. The candidate oncoprotein Bcl-3 is an antagonist of p50/N F-кB-mediated inhibition. Nature 359: 339-342.

Franzoso, G., V. Bours, V. Azarenko, S. Park, M. Tomita- 
Yamaguchi, T. Kanno, K. Brown, and U. Siebenlist. 1993. The oncoprotein Bcl-3 can facilitate N F-kB-mediated transactivation by removing inhibiting $p 50$ homodimers from select $\kappa$ B sites. EMBO J. 12: 3893-3901.

Franzoso, G., L. Carlson, T. Scharton-Kersten, E.W. Shores, S. Epstein, A. Grinberg, T. Tran, E. Schacter, A. Leonardi, M. Anver, P. Love, A. Sher, and U. Siebenlist. 1997. Critical roles for the Bcl-3 oncoprotein in T cell-mediated immunity, splenic microarchitecture, and germinal center reactions. Immunity 6: 479-490.

Franzoso, G., L. Carlson, L. Poljak, E.W. Shores, S. Epstein, A. Leonardi, A. Grinberg, T. Tran, T. Scharton-Kersten, M. Anver, P. Love, K. Brown, and U. Siebenlist. 1998. Mice deficient in NF-кB/p52 present with deficits in humoral responses, germinal center reactions and splenic microarchitecture. J. Exp. Med. (in press).

Fujita, T., G.P. N olan, H.-C. Liou, M.L. Scott, and D. Baltimore. 1993. The candidate proto-oncogene bcl-3 encodes a transcriptional coactivator through NF-kB p50 homodimers. Genes \& Dev. 7: 1354-1363.

Gerondakis, S., A. Strasser, D. Metcalf, G. Grigoriadis, J.-P. Scheerlinck, and R.J. Grumont. 1996. Rel-deficient T cells exhibit defects in production of interleukin 3 and granulocyte-macrophage colony-stimulating factor. Proc. Natl. Acad. Sci. 93: 3405-3409.

Grigoriades, A.E., Z.Q. Wang, M.G. Cecchini, W. Hofstetter, R. Felix, H.A. Fleisch, and E.F. Wagner. 1994. c-Fos: A key regulator of osteoclast-macrophage lineage determination and bone remodeling. Science 266: 443-448.

Grigoriadis, G., Y. Zhan, R.J. Grumont, D. Metcalf, E. Handman, C. Cheers, and S. Gerondakis. 1996. The Rel subunit of NF-кB-like transcription factors is a positive and negative regulator of macrophage gene expression: Distinct roles for Rel in different macrophage populations. EMBO J. 15: 70997107.

Horowitz, M.C. 1993. Cytokines and estrogen in bone: Antiosteoporotic effects. Science 260: 626-627.

Horwitz, B.H., M.L. Scott, S.R. Cherry, R.T. Bronson, and D. Baltimore. 1997. Failure of Iymphopoiesis after adoptive transfer of NF-kB-deficient fetal liver cells. Immunity 6: 765-772.

Hughes, D.E., A. Dai, J.C. Tiffee, H.H. Li, G.R. Mundy, and B.F. Boyce. 1996. Estrogen promotes apoptosis of murine osteoclasts mediated by TGF $\beta$. Nature Med. 2: 1132-1136.

Jameson, S.C., K.A. Hogquist, and M.J. Bevan. 1995. Positive selection of thymocytes. Annu. Rev. Immunol. 13: 93-126.

Jilka, R., G. Hangoc, G. Girasole, G. Passeri, D.C. Williams, J.S. A brams, B. Boyce, H. Boxmeyer, and S.C. M anolagas. 1992. Increased osteoclast devel opment after estrogen loss: M ediation by interleukin-6. Science 257: 88-91.

Jimi, E., T. Shuto, and T. Koga. 1995. M acrophage colony-stimulating factor and interleukin la maintain the survival of osteoclast-like cells. Endocrinology 136: 808-811.

Kampinga, J., S. Berges, R.L. Boyd, P. Brekelmans, M. Colic, W. vanEwijk, M.D. Kendall, H. Ladyman, P. N ieuwenhusi, and M.A. Ritter. 1989. Thymic epithelial antibodies: Immunohistochemical analysis and introduction of nomenclature. Thymus 13: 165-173.

Kimble, R.B., A.B. Matayoshi, J.L. Vannice, C. Williams, and R. Pacfici. 1995. Simultaneous block of interleukin-1 and tumor necrosis factor is required to completely prevent bone loss in the early postovariectomy period. Endocrinology 136: 3054-3061.

Kirillov, A., B. Kistler, R. Mostoslavsky, H. Cedar, T. Wirth, and Y. Bergman. 1996. A role for nuclear N F-кB in B-cell specific demethylation of the Igк locus. Nature Genet. 13: 435-441.
Kitazawa, R., R.B. Kimble, J.L. Vannice, V.T. Kung, and R. Pacifici. 1994. Interleukin-1 receptor antagonist and tumor necrosis factor binding protein decrease osteoclast formation and bone resorption in ovariectomized mice. J. Clin. Invest. 94: 2397-2406.

Klement, J.F., N .R. Rice, B.D. Car, S.J. Abbondanzo, G.D. Powers, P.H. Bhatt, C.H. Chen, C.A. Rosen, and C.L. Stewart.

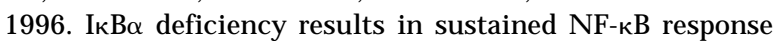
and severe widespread dermatitis in mice. Mol. Cell Biol. 16: 2341-2349.

Kontgen, F., R.J. Grumont, A. Strasser, D. Metcalf, R. Li, D. Tarlinton, and S. Gerondakis. 1995. Mice lacking the c-rel proto-oncogene exhibit defects in lymphocyte proliferation, humoral immunity, and interleukin-2 expression. Genes \& Dev. 9: 1965-1977.

Lam, K.-P., R. Kühn, and K. Rajewsky. 1997. In vivo ablation of surface immunogl obulin on mature B cells by inducible gene targeting results in rapid cell death. Cell 90: 1073-1083.

Laufer, T.M., J. DeKoning, J.S. Markowitz, D. Lo, and L.H. Glimcher. 1996. Unopposed positive sel ection and autoreactivity in mice expressing class II MHC only on thymic cortex. Nature 383: 81-85.

Leenen, P.J., M.F. DeBruijn, J.S. Voerman, P.A. Campbell, and W. vanEwijk. 1994. Markers of mouse macrophage development detected by monocl onal antibodies. J. I mmunol. Methods 174: $5-19$.

Liou, H.C., W.C. Sha, M.L. Scott, and D. Baltimore. 1994. Sequential induction of N F-kB / Rel family proteins during Bcell terminal differentiation. Mol. Cell. Biol. 14: 5349-5359.

Liu, Y.-J. and J. Banchereau. 1996. Mutant mice without B Iymphocyte follicles. J. Exp. Med. 184: 1207-1211.

Liu, Z.G., H. Hsu, D.V. Goeddel, and M. Karin. 1996. Dissection of TNF receptor 1 effector functions: JNK activation is not linked to apoptosis while NF-кB activation prevents cell death. Cell 87: 565-576.

Lowe, C., T. Yoneda, B.F. Boyce, H. Chen, G.R. Mundy, and P. Soriano. 1993. Osteopetrosis in src deficient mice is due to an autonomous defect of osteoclasts. Proc. Natl. Acad. Sci. 90: 4485-4489.

MacLennan, I.C.M. 1994. Germinal centers. Annu. Rev. Immunol. 12: 117-139.

Melchers, F. 1997. The devel opment of Iymphocytes. Int. Arch. Allergy Immunol. 113: 11-13.

Melton, L.J. 1995. How many women have osteoporosis now? J. Bone Miner. Res. 10: 175-177.

Michaelson, J.S., M. Singh, C.M. Snapper, W.C. Sha, D. Baltimore, and B.K. Birshtein. 1996. Regulation of 3'IgH enhancers by a common set of factors, including $\mathrm{\kappa B}$-binding proteins. J. Immunol. 156: 2828-2839.

Minkin, C. 1982. Bone acid phosphatase: Tartrateresistant acid phosphatse as a marker of osteoclast function. Calcif. Tissue Int. 34: 285-290.

Miyamoto, S., M.J. Schmitt, and I.M. Verma. 1994. Qualitative changes inthe subunit composition of $\kappa \mathrm{B}$-binding complexes during murine B-cell differentiation. Proc. Natl. Acad. Sci. 91: 5056-5060.

Mombaerts, P., J. Iacomini, R.S. Johnson, K. Herrup, S. Tonegawa, and V.E. Papaionannou. 1992. RAG-1-deficient mice have no mature B and T Iymphocytes. Cell 68: 869877.

Ozaki, K., H. Takeda, H. Iwahashi, A. Kitano, and S. Hanazawa. 1997. N F-кB inhibitors stimulate apoptosis of rabbit mature osteoclasts and inhibit bone resorption by these cells. FEBS Lett. 410: 297-300.

Pacifici, R., C. Brown, E. Puschck, E. Friederick, R. McCracken, D. Maggio, E. Slatopolsky, and L.V. Avioli. 1991. Effect of 
surgical menopause and estrogen replacement on cytokine release from human blood mononuclear cells. Proc. Natl. Acad. Sci. 88: 5134-5138.

Popoff, S.N . and S.C. Marks, Jr. 1995. The heterogeneity of the osteopetroses reflects the diversity of cellular influences during skel etal development. Bone 17: 437-445.

Rajewsky, K. 1996. Clonal selection and learning in the antibody system. Nature 381: 751-758.

Robey, E. and B.J. Fowlkes. 1994. Selective events in T cell development. Annu. Rev. Immunol. 12: 675-705.

Scherer, D.C., J.A. Brockman, H.H. Bendall, G.M. Zhang, D.W. Ballard, and E.M. OItz. 1996. Corepression of RelA and c-Rel inhibits immunogl obulin kappa gene transcription and rearrangement in precursor B Iymphocytes. Immunity 6: 563574.

Schwarz, E.M., P. Krimpenfort, A. Berns, and I.M. Verma. 1997. Immunological defects in mice with a argeted disruption in Bcl-3. Genes \& Dev. 11: 187-197.

Sha, W.C., H.C. Liou, E.I. Tuomanen, and D. Baltimore. 1995. Targeted disurption of the p50 subunit of NF-кB leads to multifocal defects in immune responses. Cell 80: 321-330.

Shaffer, A.L., A. Peng, and M.S. Schlissel. 1997. In vivo ococupancy of the $\kappa$ light chain enhancers in primary pro- and pre-B cells: A model for $\kappa$ locus activation. Immunity 6: 131143.

Shores, E.W., K. Huang, T. Tran, E. Lee, A. Grinberg, and P.E. Love. 1994. Role of TCR chain in T cell development and selection. Science 266: 1047-1050.

Siebenlist, U., G. Franzoso, and K. Brown. 1994. Structure, regulation and function of N F-кB. Annu. Rev. Cell Biol. 10: 405455.

Snapper, C.M., F.R. Rosas, R. Zelazowski, M.A. M oorman, M.R. Kehry, R. Bravo, and F. Weih. 1996a. B cells lacking RelB are defective in proliferative responses, but undergo normal $B$ cell maturation to Ig secretion and Ig class switching. J. Exp. Med. 184: 1537-1541.

Snapper, C.M., P. Zelazzowski, F.R. Rosas, M.R. Kehry, M. Tian, D. Baltimore, and W.C. Sha. 1996b. B cells from p50/ NF-кB knock-out mice have selective defects in proliferation, differentiation, germ-line $\mathrm{CH}$ transcription, and Ig class switching. J. Immunol. 156: 183-191.

Soriano, P., C. Montgomery, R. Geske, and A. Bradley. 1991. Targeted disruption of the c-src proto-oncogene leads to osteopetrosis in mice. Cell 64: 693-702.

Surh, C.D., E.K. Gao, H. Kosaka, D. Lo, C. Ahn, D.B. M urphy, L. Karlsson, P. Peterson, and J. Sprent. 1992. Two subsets of epithelial cells in thethymic medulla. J. Exp. Med. 176: 495505.

Takahashi, N., N. Udagawa, T. A katsu, H. Tanaka, Y. Isogai, and T. Suda. 1991. Deficiency of osteoclasts in osteopetrotic mice is due to a defect in the local microenviornment provided by osteoblastic cells. Endocrinology 128: 1792-1796.

Tondravi, M.M., S.R. McKercher, K. Anderson, J.M. Erdmann, M. Quiroz, R. Maki, and S.L. Teitel baum. 1997. Osteopetrosis in mice lacking haematopoi etic transcription factor PU.1. Nature 386: 81-84.

Turner, M., P.J. Mee, P.S. Costello, O. Williams, A.A. Price, L.P. Duddy, M.T. Furlong, R.L. Geahlen, and V.L. Tybulewicz. 1995. Perinatal lethality and blocked B-cell development in mice lacking the tyrosine kinase Syk. Nature 378: 298-302.

Van Antwerp, D.J., S.J. Martin, T. Kafri, D.R. Green, and I.M. Verma. 1996. Suppression of TNF- $\alpha$-induced apoptosis by NF-кB. Science 274: 787-789.

Verma, I.M., J.K. Stevenson, E.M. Schwarz, D. Van Antwerp, and S. Miyamoto. 1995. Rel/NF-кB/ІкB family intimate tales of association and dissociation. Genes \& Dev. 9: 2723-
2735.

Wang, C.Y., M.Y. Mayo, and A.S. Baldwin. 1996. TN F- and cancer therapy-induced apoptosis: Potentiation by inhibition of NF-кB. Science 274: 784-787.

Wang, Z.-Q., C. OVitt, A.E. Grigoriadis, U. Mohle-Steinlein, U. Ruther, and E.F. Wagner. 1992. Bone and haematopoietic defects in mice lakcing c-Fos. Nature 360: 741-745.

Weih, F., D. Carrasco, S.K. Durham, D.S. Barton, C.A. Risszo, R.-P. Ryseck, S.A. Lira, and R. Bravo. 1995. Multiorgan inflammation and hematopoi etic abnormalities in mice with a targeted disruption of RelB, a member of the N F-kB/Rel family. Cell 80: 331-340.

Weih, F., S.K. Durham, D.S. Barton, W.C. Sha, D. Baltimore, and R. Bravo. 1996. Both multiorgan inflammation and myeloid hyperplasia in RelB-deficient mice are T cell dependent. J. Immunol. 157: 3974-3979.

- - . 1997. p50-N F-кB complexes partially compensate for the absence of RelB: Severely increased pathology in p50 $(-1$ $\rightarrow$ rel $\mathrm{B}(-\rightarrow)$ double-knockout mice. J. Exp. Med. 185: 13591370.

Wu, M., H. Lee, R.E. Bellas, S.L. Schauer, M. Arsura, K. Katz, M.J. FitzGerald, T.L. Rothstein, D.H. Sherr, and G.E. Sonenshein. 1996. Inhibition of NF-kB/Rel induces apoptosis of murine B cells. EMBO J. 15: 4682-4690.

Yoshida, H., S. Hayashi, T. Kunisada, M. Ogawa, S. Nishikawa, H. Okamura, T. Sudo, L.D. Schultz, and S. Nihikawa. 1990. The murine mutation osteopetrosis is in the coding region of the macrophage colony stimulating factor gene. Nature 345: $442-444$. 


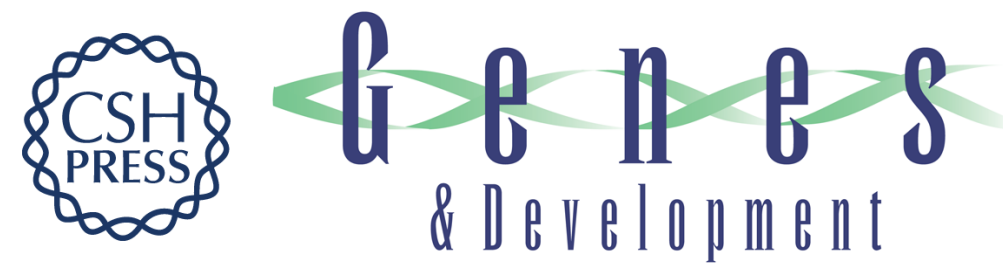

\section{Requirement for NF- $\mathrm{kB}$ in osteoclast and B-cell development}

Guido Franzoso, Louise Carlson, Lianping Xing, et al.

Genes Dev. 1997, 11:

Access the most recent version at doi:10.1101/gad.11.24.3482

References This article cites 79 articles, 31 of which can be accessed free at: http://genesdev.cshlp.org/content/11/24/3482.full.html\#ref-list-1

License

Email Alerting Receive free email alerts when new articles cite this article - sign up in the box at the top Service right corner of the article or click here.

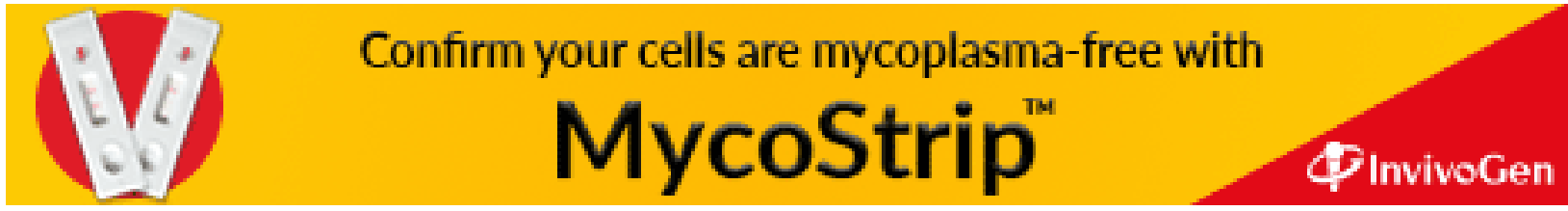

